OPEN ACCESS

Understanding Degradation Effects of Elevated Temperature Operating Conditions in Polymer Electrolyte Water Electrolyzers

To cite this article: Steffen Garbe et al 2021 J. Electrochem. Soc. 168044515

View the article online for updates and enhancements.

239th ECS Meeting with IMCS18

DIGITAL MEETING • May 30-June 3, 2021

Live events daily • Free to register
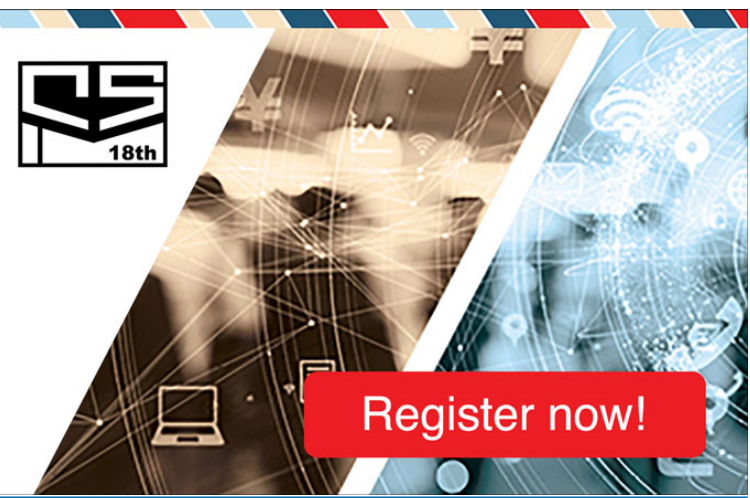


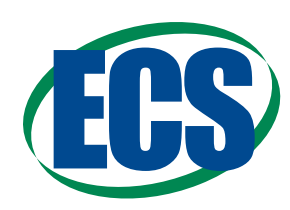

\title{
Understanding Degradation Effects of Elevated Temperature Operating Conditions in Polymer Electrolyte Water Electrolyzers
}

\author{
Steffen Garbe, ${ }^{1, *}$ (I) Jonas Futter, ${ }^{1}$ (i) Ayush Agarwal, ${ }^{2,3}$ Mohamed Tarik, ${ }^{2}$ (i) Adrian \\ A. Mularczyk, ${ }^{1}$ (D) Thomas J. Schmidt, ${ }^{1,4, * *}$ (D) and Lorenz Gubler ${ }^{1,3, * * *, z}$ (D) \\ ${ }^{1}$ Electrochemistry Laboratory, Paul Scherrer Institut, 5232 Villigen PSI, Switzerland \\ ${ }^{2}$ Bioenergy and Catalysis Laboratory, Paul Scherrer Institut, 5232 Villigen PSI, Switzerland \\ ${ }^{3}$ École Polytechnique Fédérale de Lausanne (EPFL), ENAC IIE GR-LUD, 1015 Lausanne, Switzerland \\ ${ }^{4}$ Laboratory of Physical Chemistry, ETH Zürich, 8093 Zürich, Switzerland
}

\begin{abstract}
The cost of polymer electrolyte water electrolysis (PEWE) is dominated by the price of electricity used to power the water splitting reaction. We present a liquid water fed polymer electrolyte water electrolyzer cell operated at a cell temperature of $100{ }^{\circ} \mathrm{C}$ in comparison to a cell operated at state-of-the-art operation temperature of $60{ }^{\circ} \mathrm{C}$ over a $300 \mathrm{~h}$ constant current period. The hydrogen conversion efficiency increases by up to 5\% at elevated temperature and makes green hydrogen cheaper. However, temperature is a stress factor that accelerates degradation causes in the cell. The PEWE cell operated at a cell temperature of $100{ }^{\circ} \mathrm{C}$ shows a 5 times increased cell voltage loss rate compared to the PEWE cell at $60^{\circ} \mathrm{C}$. The initial performance gain was found to be consumed after a projected operation time of $3,500 \mathrm{~h}$. Elevated temperature operation is only viable if a voltage loss rate of less than $5.8 \mu \mathrm{V} \mathrm{h}^{-1}$ can be attained. The major degradation phenomena that impact performance loss at $100{ }^{\circ} \mathrm{C}$ are ohmic $(49 \%)$ and anode kinetic losses (45\%). Damage to components was identified by post-test electron-microscopic analysis of the catalyst coated membrane and measurement of cation content in the drag water. The chemical decomposition of the ionomer increases by a factor of 10 at $100{ }^{\circ} \mathrm{C}$ vs $60{ }^{\circ} \mathrm{C}$. Failure by short circuit formation was estimated to be a failure mode after a projected lifetime $3,700 \mathrm{~h}$. At elevated temperature and differential pressure operation hydrogen gas cross-over is limiting since a content of $4 \%$ hydrogen in oxygen represents the lower explosion limit.

(C) 2021 The Author(s). Published on behalf of The Electrochemical Society by IOP Publishing Limited. This is an open access article distributed under the terms of the Creative Commons Attribution Non-Commercial No Derivatives 4.0 License (CC BYNC-ND, http://creativecommons.org/licenses/by-nc-nd/4.0/), which permits non-commercial reuse, distribution, and reproduction in any medium, provided the original work is not changed in any way and is properly cited. For permission for commercial reuse, please email: permissions@ioppublishing.org. [DOI: 10.1149/1945-7111/abf4ae]
\end{abstract}

Manuscript submitted January 8, 2021; revised manuscript received March 16, 2021. Published April 14, 2021. This paper is part of the JES Focus Issue on Proton Exchange Membrane Fuel Cell and Proton Exchange Membrane Water Electrolyzer Durability.

Supplementary material for this article is available online

Green hydrogen could become a major energy vector in a Power-to$\mathrm{X}$ scenario by replacing carbon based fuels to reduce $\mathrm{CO}_{2}$ emissions. ${ }^{1}$ One of the key technologies to produce green hydrogen is polymer electrolyte water electrolysis (PEWE). ${ }^{2}$ Besides the missing infrastructure, high production costs in comparison to hydrogen generated from fossil fuels is a barrier to enter a large scale market penetration. For continuous PEWE operation the hydrogen price is dominated by the large operational costs due to high electricity consumption. ${ }^{3}$ In order to reduce electricity consumption the efficiency of PEWE needs to be increased, which would allow lower energy input for generating an equal amount of hydrogen or higher hydrogen production rate at an equal energy input. PEWE efficiency can be increased by increasing the operating temperature. ${ }^{4}$ This leads to a decrease in the minimum electrical energy required for the water splitting reaction as well as decrease the kinetic limitations, i.e. kinetic and ohmic overpotentials, at practical current densities. ${ }^{5}$ Typical industrial PEWE operate at $50{ }^{\circ} \mathrm{C}-60{ }^{\circ} \mathrm{C}$ at constant load and show no detectable performance voltage loss rate over a 40,000 h life span. ${ }^{6}$ In the context of a project funded by the US Department of Energy (DOE), an elevated operating temperature $\left(90^{\circ} \mathrm{C}\right)$ has been proposed as an operational target to contribute to decrease green hydrogen production costs. ${ }^{7}$ At the same time, PEWE lifetime is required to increase up to $130,000 \mathrm{~h}^{2}$

Operating PEWE cells at elevated temperature increases the stress on the materials and components and therefore accelerates degradation. Recently, high attention has been devoted towards stress factors, degradation mechanisms and durability in PEWE. ${ }^{8-17}$ Catalyst type ${ }^{18}$ catalyst ink composition and preparation, ${ }^{19}$ catalyst layer loading, ${ }^{20}$ catalyst coated membrane (CCM) preparation, ${ }^{21}$ CCM compression, ${ }^{14}$ water purity, ${ }^{22}$ membrane type, ${ }^{23}$ intermittent operation $^{10}$ and current density load ${ }^{24,25}$ can all have an impact on PEWE lifetime. To the best of our knowledge, there are three studies dealing with PEWE degradation in the context of elevated temperature operation $\left(\geqslant 90^{\circ} \mathrm{C}\right) .8,9,16$ LaConti et al. found that the rate of chemical decomposition of a Nafion ${ }^{\circledR} 117$ membrane increased by 2 orders of magnitude upon increase of the operating temperature from $60{ }^{\circ} \mathrm{C}$ to $149^{\circ} \mathrm{C}$, and the projected lifetime of the cell being reduced by the same factor. ${ }^{16}$ Similar to polymer electrolyte fuel cells, the key factor for chemical decomposition is believed to be oxygen crossover through the polymer membrane triggering the formation of radicals, which attack the polymer electrolyte. ${ }^{26}$ Recently, Frensch et al. found a 100 -fold larger decrease in performance and a 40 -fold increased extent of chemical decomposition in PEWE using a N115 membrane when increasing the operating temperature from $60{ }^{\circ} \mathrm{C}$ to $90{ }^{\circ} \mathrm{C} .{ }^{9}$ The decrease in performance was found to be of purely ohmic nature and was assumed to be caused by titanium passivation of the porous transport layer. In the present work, we investigated the degradation effects of a PEWE cell using commercial cell components at elevated temperature $\left(100{ }^{\circ} \mathrm{C}\right)$ compared to a cell operated at the state-of-the-art operating temperature $\left(60{ }^{\circ} \mathrm{C}\right)$. Degradation effects were determined by electrochemical characterization methods, gas chromatography and ion chromatography (IC). An attempt is presented to match the observed degradation effects with degradation causes by PEWE system and cell component analysis. Feed and drag water were analyzed using inductivelycoupled plasma mass spectrometry (ICP-MS) and conductivity measurements. Further, scanning electron microscopy (SEM) and coupled energy dispersive X-ray (EDX) mapping were used for a post-test characterization of used cell components. Three PEWE shut down criteria were identified and compared.

\section{Experimental}

*Electrochemical Society Student Member.

**Electrochemical Society Fellow.

***Electrochemical Society Member.

${ }^{\mathrm{z}}$ E-mail: lorenz.gubler@psi.ch
Electrolysis test-station.-Experiments were performed with a home-built electrolysis test bench comprising an anode and cathode 
Table I. Voltage loss rates for PEWE cell 1 and cell 2 operated at constant current density of $2 \mathrm{~A} \mathrm{~cm}^{-2}$. The voltage loss rate $\Delta E_{j=\text { const }} / \Delta t$ was calculated by dividing the start and end voltage of the constant current period by the operation time $\Delta t . \Delta E_{E-j(T)} / \Delta t$ is calculated by the voltage difference at $2 \mathrm{~A} \mathrm{~cm}^{-2}$ in polarization curves. Both cells were operated using similar catalyst coated membranes consisting of a $\mathrm{IrO}_{2} / \mathrm{TiO}_{2}$ anode catalyst (Umicore), a Pt/C cathode catalyst (Tanaka) and a N117 Nafion membrane (IonPower).

\begin{tabular}{|c|c|c|c|c|c|}
\hline \multirow{2}{*}{ Name } & \multirow[b]{2}{*}{$\begin{array}{l}\text { Temperature } \\
T \quad{ }^{\left.\circ{ }^{\circ} \mathrm{C}\right]}\end{array}$} & \multirow[b]{2}{*}{$\begin{array}{l}\text { Operation time } \\
\Delta t \quad \text { [h] }\end{array}$} & \multicolumn{3}{|c|}{ Voltage loss rate at $2 \mathrm{~A} \mathrm{~cm}^{-2}$} \\
\hline & & & $\begin{array}{c}j=\text { const. at } T \\
\Delta E_{j=\text { const }} / \Delta t \\
{\left[\mu \mathrm{V} \mathrm{h}^{-1}\right]}\end{array}$ & $\begin{array}{l}E-j \text { at } T \\
\Delta E_{E-j(T)} / \Delta t \\
{\left[\mu \mathrm{V}^{-1} \mathrm{~h}^{-1}\right]}\end{array}$ & $\begin{array}{c}E-j \text { at } 60{ }^{\circ} \mathrm{C} \\
\Delta E_{E-j(60}{ }^{\circ} \mathrm{C} / \\
{\left[\mu \mathrm{V} \mathrm{h}^{-1}\right]}\end{array}$ \\
\hline Cell 1 & 60 & 308 & +29 & -13 & -13 \\
\hline Cell 2 & 100 & 294 & +126 & +346 & +598 \\
\hline
\end{tabular}

gas/water loop (Fig. S1 available online at stacks.iop.org/JES/168/ 044515/mmedia). PTFE tubes were used to emit a minimum of ions. Deionized water $(18.2 \mathrm{MOhm} \mathrm{cm})$ was pumped into the anode gas/ water separator and the water level was kept constant $( \pm 20 \mathrm{ml})$ via a level sensor during experiments. The water was circulated $\left(1200 \mathrm{ml} \mathrm{min}^{-1}\right)$ using a gear pump (ISMATEC, REGLO-ZS Digital) into a plate heat exchanger (Alfa Laval, AlfaNova 14-10H), which cooled down the water to a temperature of about $30^{\circ} \mathrm{C}$. An ion exchange resin (BWT, max. operation temperature of $50^{\circ} \mathrm{C}$ ) was placed in line to ensure the purity of the water. The purity of the water was determined by a conductivity sensor with integrated resistance thermometer (JUMO tecLine CR). From there the water was fed via a fluoropolymer inline heater (Process Technology, TIH3) into the cell. All experiments were performed at a balanced pressure of 3 bar $_{\mathrm{a}}$ applied by a pressure regulation system (PC, Bronkhorst) located downstream of the gas water separators. Condensed water was trapped in an inline gas/water separator on the anode side after the pressure regulation. The content of $\mathrm{H}_{2}$ in $\mathrm{O}_{2}$ was measured at the gas outlet using an Eaton $\mathrm{K} 1550$ gas analyzer (calibrated in $\mathrm{O}_{2}, 0.1 \% \mathrm{H}_{2}$ in $\mathrm{O}_{2}, 1 \% \mathrm{H}_{2}$ in $\mathrm{O}_{2}, 2 \% \mathrm{H}_{2}$ in $\mathrm{O}_{2}$ ). The electro-osmotically dragged water was discarded periodically from the cathodic gas-water separator. The discarded water was monitored with a second conductivity probe. For the hydrogen-nitrogen halfcell cyclovoltamograms and potentiostatic electrochemical impedance spectroscopy measurements (PEIS) hydrogen and nitrogen was fed into cathode and anode compartments, respectively, via mass flow controllers (MFC, Bronkhorst).

The water and cell housing temperatures were measured using Pt100 flexible resistance thermometers (Electronic Sensor GmbH,
Pt100A 10/25). The water temperature was measured at the inlet and outlet of the cell with thermometers inserted into Swagelok fittings (Electronic Sensors, SW-Druck-Pt100 A-M 6). The cell housing temperature was measured in a hole drilled into the current collector directly behind the flow fields of anode and cathode. The inlet water temperature was controlled by the inlet of the cell. The cell housing temperature on each electrode side was controlled separately with two heating cartridges inserted into the end plates of anode and cathode. A multi-zone temperature controller (Elotech, R2400S) was used to regulate the water heater and the cartridges.

Electrolysis cell.-A PEWE single cell with an active area of 25 $\mathrm{cm}^{2}$ comprising a titanium parallel flow field (FF) on both sides was used to accommodate a commercial sintered titanium porous transport layer (PTL, Sika T10, GKN Sinter Metal Filters) of $1 \mathrm{~mm}$ thickness from GKN on the anode. A carbon gas diffusion layer (GDL, 2050A6060, SPECTRACARB) of $1.5 \mathrm{~mm}$ thickness was used on the cathode. A catalyst coated membrane (CCM) with in-house spray-coated catalyst layers was sandwiched between anode and cathode. The endplates of the cell were tightened with a torque of $15 \mathrm{Nm}$ giving an average compressive force of about $2 \mathrm{MPa}$.

Membrane pretreatment.-Nafion ${ }^{\circledR}$ N117 (Ion Power) was used in this study. In order to remove impurities and ensure complete protonation, Nafion ${ }^{\circledR}$ membranes were pretreated in $32.5 \%$ nitric acid at $90{ }^{\circ} \mathrm{C}$ for $1 \mathrm{~h}$ and then immersed three times in deionized water at $90{ }^{\circ} \mathrm{C}$ for $1 \mathrm{~h}$. Membranes were left to dry in air and then cut to a size of $10 \times 10 \mathrm{~cm}$ for $\mathrm{CCM}$ preparation and to $3 \times 1.2 \mathrm{~cm}$ for thermal stress tests.

Table II. Overview of degradation experiments from literature data with cells operated at comparable conditions to this work.

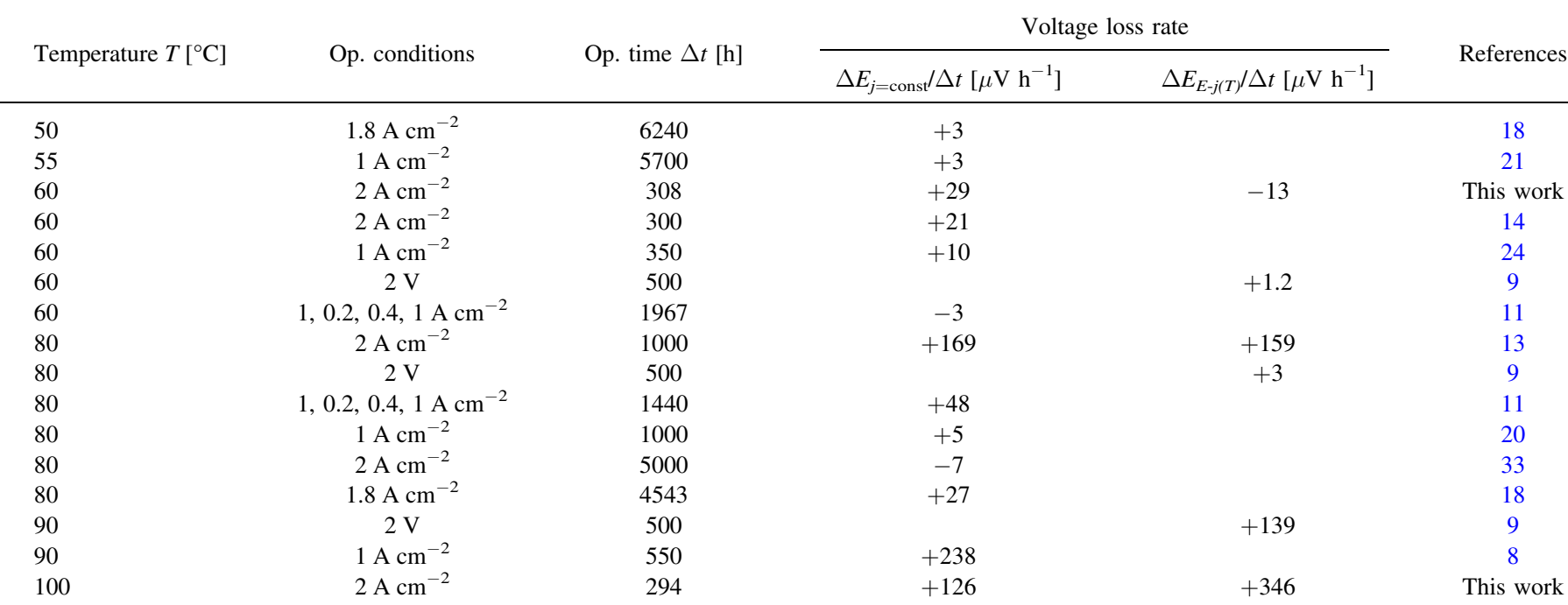



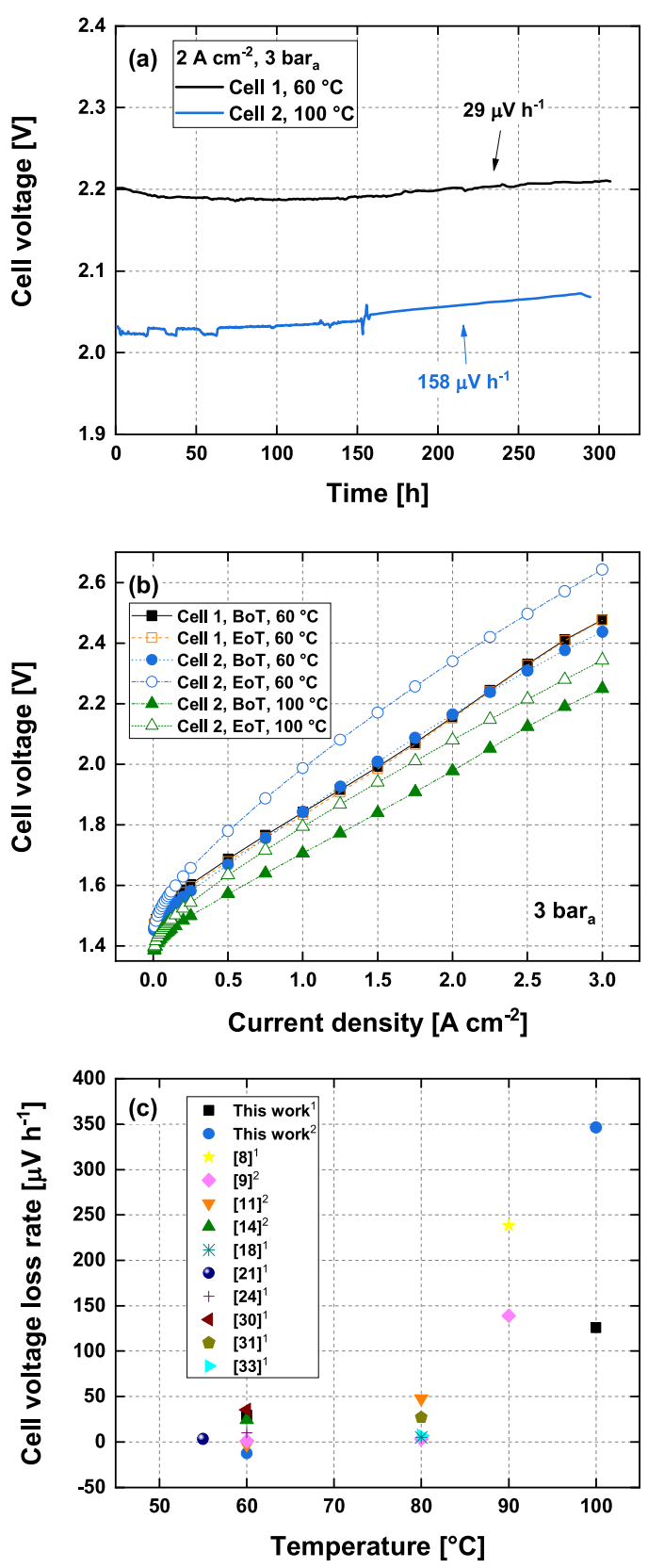

Figure 1. (a) Cell voltage as a function of operation time for the degradation experiment for cell 1 at $60{ }^{\circ} \mathrm{C}$ and cell 2 at $100{ }^{\circ} \mathrm{C}$ at a constant current density of $2 \mathrm{~A} \mathrm{~cm}^{-2}$ and $3 \mathrm{bar}_{\mathrm{a}}$. (b) Polarization curves recorded at an operation temperature of $60{ }^{\circ} \mathrm{C}$ for cell 1 (BoT at $60{ }^{\circ} \mathrm{C}$ in filled black symbols, EoT at $60{ }^{\circ} \mathrm{C}$ in empty orange symbols), cell 2 (aged at $100{ }^{\circ} \mathrm{C}$, blue), as well as polarization curves for cell 2 recorded at an operation temperature of $100^{\circ} \mathrm{C}$ before the aging experiment (BoT, filled symbols) and after the experiment (EoT, empty symbols). (c) Cell voltage loss rate as a function of temperature observed in this work compared to literature data (Table II). ${ }^{1}$ Mean voltage loss rate calculated from the cell voltage over the experiment's duration. ${ }^{2}$ Voltage loss rate calculated from the difference of polarization curves at BoT and EoT.

Preparation of catalyst coated membranes.-Before spraying, membranes were left to dry in air. The anode catalyst ink was prepared by mixing $0.85 \mathrm{ml}$ isopropanol, $2.70 \mathrm{ml}$ miliQ water, $2.54 \mathrm{ml}$ Nafion Solution (Ion Power D521, 5w\% Nafion ${ }^{\circledR}$ ) and $1 \mathrm{~g}$ of $\mathrm{IrO}_{2} / \mathrm{TiO}_{2}$ catalyst (Elyst Ir75 0480, Umicore). For the cathode catalyst ink $0.070 \mathrm{~g} \mathrm{Pt} / \mathrm{C}$ catalyst (TEC10E50E, Tanaka Kikinzoku Kogyo), $1.16 \mathrm{ml}$ ethanol, $0.71 \mathrm{ml}$ miliQ water and $0.66 \mathrm{ml}$ Nafion solution (Ion Power D521, 5w $\%$ Nafion $^{\circledR}$ ) were mixed. Both catalyst ink mixtures were sonicated for
30 min. For the CCM preparation an automatic spray coating machine (Sonotek, ExactaCoat) with an ultrasonic nozzle was used. The inks were filled into a syringe containing a magnetic stirrer. The membranes were fixed in polyoxymethylene frames and placed on a $50{ }^{\circ} \mathrm{C}$ hot plate. The inks were sprayed onto the membranes with an ink flow rate of $0.05 \mathrm{ml} \mathrm{min}^{-1}$, a nozzle height of $10 \mathrm{~mm}$ and a nozzle speed of $80 \mathrm{~mm} \mathrm{~s}^{-1}$. In order to achieve the desired loadings, a PTFE reference sheet was sprayed in parallel to every sprayed layer, and the loading was determined gravimetrically. The CCMs were dried in air for $24 \mathrm{~h}$ and subsequently weighed. The ink-spraying preparation method yielded anode loadings of $2.1 \pm 0.1 \mathrm{mg}_{\text {Ir }} \mathrm{cm}^{-2}$ and cathode loadings of $0.4 \pm 0.05 \mathrm{mg}_{\mathrm{Pt}} \mathrm{cm}^{-2}$. The cells were assembled with the CCMs in a wet state after immersion in miliQ water for $12 \mathrm{~h}$.

Cell tests.-Electrochemical characterization was performed using a SP-150 potentiostat and a VMP3B 80 A booster from Biologic before and after the degradation experiments. Cells were conditioned at $60{ }^{\circ} \mathrm{C}$ with a water flow rate of $1,200 \mathrm{ml} \mathrm{min}^{-1}$ by holding the current density at $2 \mathrm{~A} \mathrm{~cm}^{-2}$ for $48 \mathrm{~h}$. After having reached an operating temperature of $60{ }^{\circ} \mathrm{C}$, polarization curves were recorded according to the procedure reported in Ref. $5 \mathrm{H}_{2} / \mathrm{N}_{2}$ half-cell measurements were recorded according to Ref. $27,400 \mathrm{ml} \mathrm{min}^{-1} \mathrm{~N}_{2}$ and $\mathrm{H}_{2}$ were injected into the anode and cathode compartment, respectively. Catalyst layer proton resistance measurements were recorded with potentiostatic electrochemical impedance spectroscopy (PEIS) at $1.0 \mathrm{~V}$ and $1.2 \mathrm{~V}$ in the $\mathrm{H}_{2} / \mathrm{N}_{2}$ regime. ${ }^{27}$ Cyclovoltametric measurements were performed by cycling the voltage between $0.0 \mathrm{~V}$ and $1.4 \mathrm{~V}$ with a sweep rate of $50 \mathrm{mV} \mathrm{s}^{-1}$.

Cell voltage break down.-The cell voltage breakdown was performed using the Tafel analysis. ${ }^{5}$ The cell voltage loss terms are summed up as a function of the current density $j$ as follows:

$$
E_{\text {cell }}(j)=E_{\text {rev }}+\eta_{j R}(j)+\eta_{k i n}(j)+\eta_{m t x}(j)+\eta_{C L c}^{H^{+}}(j)+\eta_{C L a}^{H^{+}}(j)
$$

where $E_{r e v}$ is the reversible cell voltage, calculated from the change in the free energy of reaction as a function of temperature, and using the Nernst equation to account for the influence of the partial pressures of $\mathrm{H}_{2}$ and $\mathrm{O}_{2}$. The $\eta_{j R}$ is the ohmic overpotential resulting from membrane, interfacial and electrical resistances and is determined by high frequency resistance (HFR) measurement at $10 \mathrm{kHz}$ at each galvanostatic step during the polarization curve measurement. Subtraction of $\eta_{j R}$ from $E_{c e l l}$ gives the iR-free cell voltage $E_{i R}$. $\eta_{\text {kin }}$ is the kinetic overpotential, which is obtained by extrapolating the iR-free cell voltage in the range between $30 \mathrm{~mA} \mathrm{~cm}^{-2}$ to $120 \mathrm{~mA} \mathrm{~cm}^{-2}$ and subtracting $E_{r e v} . R_{C L c}^{H^{+}}$and $R_{C L a}^{H^{+}}$represent the proton transport resistance in the cathode catalyst layer and the anode catalyst layer, respectively. Bernt et al. showed that the $R_{C L c}^{H^{+}}$is negligibly small in PEWE and is therefore disregarded in this study. ${ }^{28} R_{C L a}^{H^{+}}$can be determined via PEIS in $\mathrm{H}_{2} / \mathrm{N}_{2}$ half-cell experiments. The remaining overpotential $\eta_{m t x}$ is assigned to mass transport limitations to the catalytically active sites.

Cell degradation experiment.-The conditions for the degradation experiment are listed in Table I. A direct current supply (HEIDEN, SM 15-200 D) provided a current density of $2 \mathrm{~A} \mathrm{~cm}^{-2}$ and the responding voltage was measured. The operation temperature was set to 60 (cell 1) and $100{ }^{\circ} \mathrm{C}$ (cell 2), for 308 and $294 \mathrm{~h}$, respectively. Hydrogen gas crossover measurements were recorded every minute during this test. The hydrogen content in oxygen was averaged over $60 \mathrm{~min}$. Water was collected periodically from the cathodic cell compartment for cation and anion analysis.

Thermal stress test.-Thermal stress tests with Nafion N117 membranes and CCMs were performed according to Albert et al.. ${ }^{29}$ 

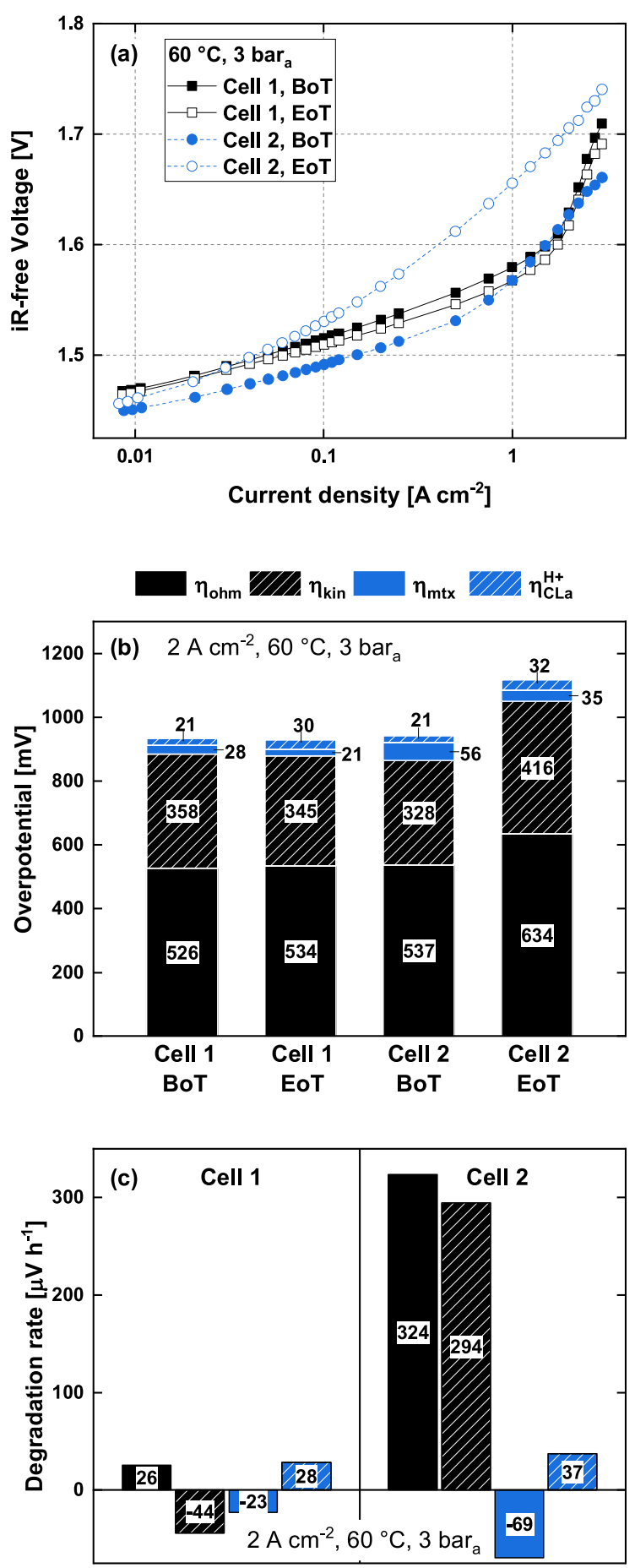

Figure 2. (a) Semi-logarithmic plot of the iR-free cell voltage as a function of the current density at an operation temperature of $60{ }^{\circ} \mathrm{C}$ and balanced pressure of 3 bar $_{a}$ for cell 1 (black), aged at $60^{\circ} \mathrm{C}$, and cell 2 (blue), aged at $100{ }^{\circ} \mathrm{C}$, before the aging experiment (BoT, filled symbols) and after the experiment (EoT, empty symbols). (b) Ohmic overpotential $\eta_{\text {ohm }}$, kinetic overpotential $\eta_{k i n}$, mass transport overpotential $\eta_{m t x}$, and ionic resistance overpotential in the anode $\eta_{C L a}^{H^{+}}$at $2 \mathrm{~A} \mathrm{~cm}^{-2}$ at BoT and EoT at $60{ }^{\circ} \mathrm{C}$ operating temperature. (c) Resulting voltage loss rate for the overpotentials of cell 1 and cell 2 calculated from (b).

Pristine CCMs were cut to $3 \times 1.2 \mathrm{~cm}$ for samples. Four membranes and two CCM samples were placed each in a $100 \mathrm{ml}$ threaded laboratory bottle with cap. $40 \mathrm{ml}$ of deionized water was added and the cap was closed. Two bottles were each immersed for $300 \mathrm{~h}$ into a stirred oil bath at $60{ }^{\circ} \mathrm{C}$ and $100{ }^{\circ} \mathrm{C}$, respectively.

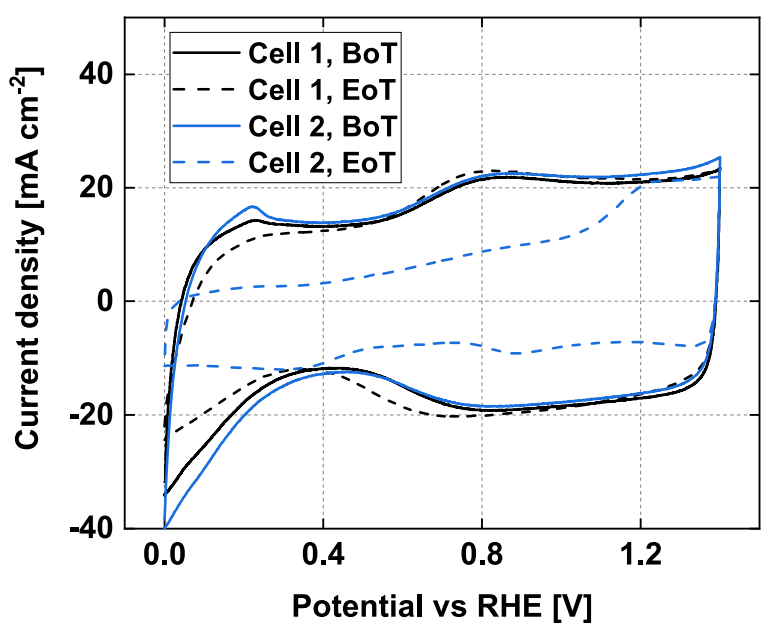

Figure 3. Cyclic voltammograms at a scan rate of $50 \mathrm{mV} \mathrm{s}^{-1}$ for the anode under $\mathrm{H}_{2} / \mathrm{N}_{2}$ conditions of cell 1 (aged at $60{ }^{\circ} \mathrm{C}$, black), cell 2 (aged at $100{ }^{\circ} \mathrm{C}$, blue) at the beginning of test (BoT) and the end of test (EoT).

SEM and EDX elemental mapping.-CCM cut-outs were immersed in liquid $\mathrm{N}_{2}$ up to $1 \mathrm{~min}$, fractured to preserve the crosssectional features, and prepared for the SEM analysis (Zeiss Supra VP55) by sputter-coating the fracture surface with a $10 \mathrm{~nm}$ thick $\mathrm{Cr}$ layer. The acceleration voltage of the SEM was $20 \mathrm{kV}$, with a working distance between $9 \mathrm{~mm}$ to $10 \mathrm{~mm}$ and an aperture of $60 \mu \mathrm{m}$. Membrane thickness was determined by thickness measurements of 400-fold magnified CCM cross-sections at 5 different locations of the CCM. Catalyst layer thickness was determined at a magnification of 2000 on 20 different catalyst layer segments. EDX mapping was used to detect the iridium, titanium and platinum content and distribution in the CCM cross-section. EDX data was processed by applying a baseline correction.

Ion analysis.-Fluoride ions of the cathode drag water and the thermal stress test water were analyzed using ion-chromatography (Metrohm 882 Compact) with a detection limit of $1 \mathrm{ppb}$. The cathode drag water was analyzed for traces of titanium, iridium and platinum using Agilent 7700x ICP-MS. Each sample was acidified to $0.5 \% \mathrm{HCl}$ for analysis. The instrument parameters were set as follows: power $1350 \mathrm{~W}$, sampling depth $10 \mathrm{~mm}$, carrier gas (argon) flow rate $0.931 \mathrm{~min}^{-1}$. Two isotopes of each element (namely ${ }^{47} \mathrm{Ti}$, ${ }^{49} \mathrm{Ti},{ }^{191} \mathrm{Ir},{ }^{193} \mathrm{Ir},{ }^{194} \mathrm{Pt}$, and ${ }^{195} \mathrm{Pt}$ ) were measured with an integration time of $0.10 \mathrm{~s}$ in spectrum mode with three replicates and 100 sweeps per replicate. Due to low interferences at the $\mathrm{m} / \mathrm{z}$ of Ir and $\mathrm{Pt}$ isotopes, no gas was used in the collision cell. The quantification was carried out using external calibration with commercial standards from Merck (Titanium Standard Solution, $\mathrm{TiCl}_{4}$ in $5 \mathrm{M} \mathrm{HCl}$ ) and Inorganic Ventures (ICP Precious Metals Std, in 10\% v/v Hydrochloric Acid). The calibration curve was drawn using five standard points with concentrations of $0,0.1,1,10$ and 100 parts per billion ( $\mathrm{ppb}$ ) concentration. The sensitivity, limit of detection, and limit of quantification for the isotopes are listed in the Supplemental Material.

\section{Results and Discussion}

Performance loss.-Figure 1a shows the cell voltage for cell 1 operated at $60{ }^{\circ} \mathrm{C}$ and cell 2 operated at $100{ }^{\circ} \mathrm{C}$ over the time of the degradation experiment with a mean voltage loss rate of $\Delta E_{j=\text { const }}$ $\Delta t=+29 \mu \mathrm{V} \mathrm{h}^{-1}$ and $\Delta E_{j=\text { const }} / \Delta t=+158 \mu \mathrm{V} \mathrm{h}^{-1}$, respectively. Voltage loss rates throughout this work are assigned a positive sign if there is a loss in performance (i.e., increase in cell voltage) between before and after the degradation experiment and a negative sign if there is an increase in performance (i.e., decrease in cell voltage). The polarization curves for cell 1 and cell 2 before and after the degradation experiment recorded at an operation temperature of $60{ }^{\circ} \mathrm{C}$ and for cell 2 

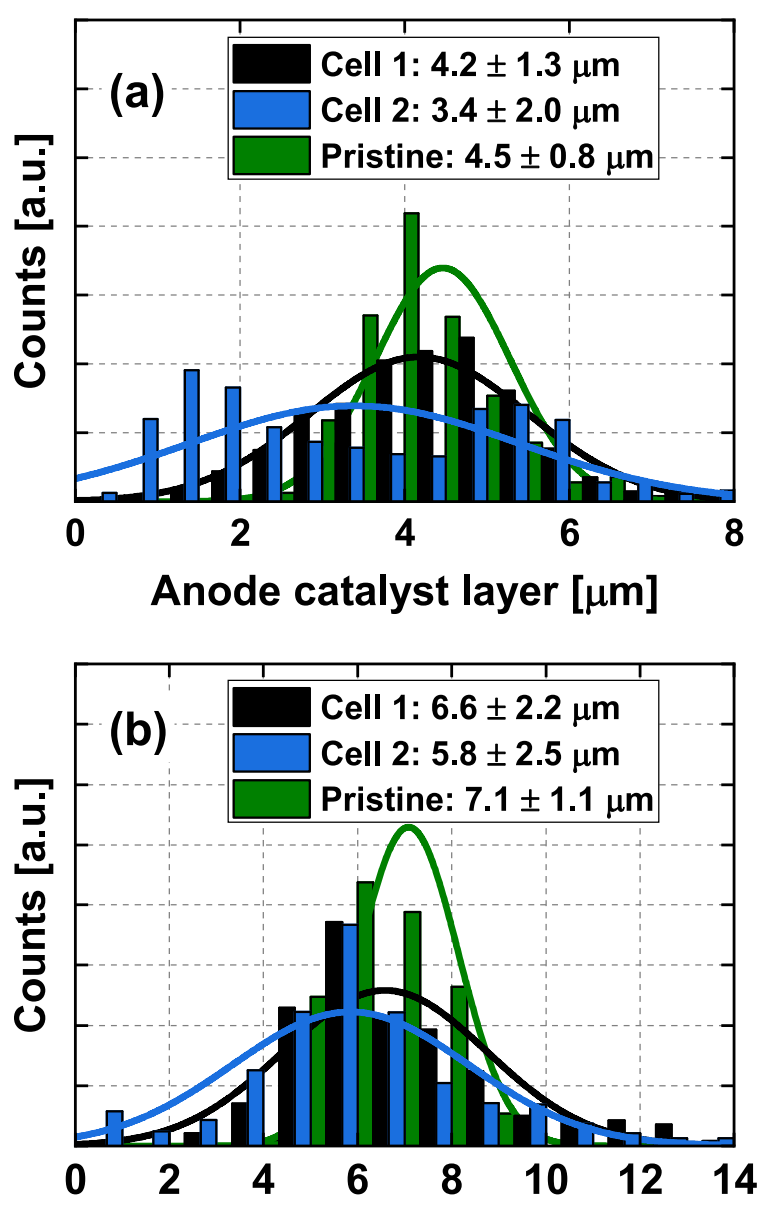

Cathode catalyst layer $[\mu \mathrm{m}]$

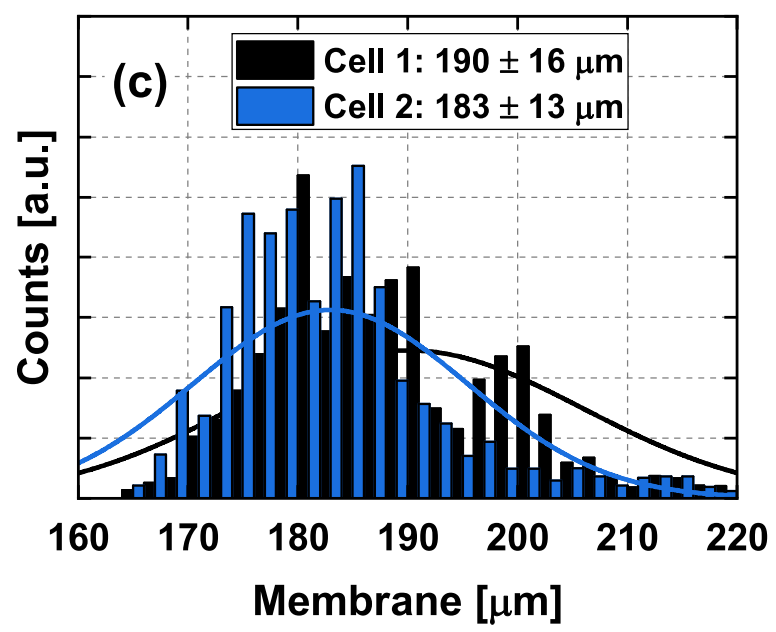

Figure 4. Thickness distribution from scanning electron microscopy images of the the anode catalyst layer (a), the cathode calayst layer (b) and the membrane (c) for cell 1 (aged at $60{ }^{\circ} \mathrm{C}$, black), cell 2 (aged at $100{ }^{\circ} \mathrm{C}$, blue) and a pristine cataylst coated membrane (green).

recorded at $100{ }^{\circ} \mathrm{C}$ operation temperature are shown in Fig. 1b. At the beginning of test (BoT) there is no significant difference in voltage observable between cell 1 and cell 2 at $60{ }^{\circ} \mathrm{C}$. With an increase in operation temperature from $60{ }^{\circ} \mathrm{C}$ to $100{ }^{\circ} \mathrm{C}$ of cell 2, polarization curves at BoT resulted in a lowering of cell voltage of $168 \mathrm{mV}$ at $2 \mathrm{~A} \mathrm{~cm}^{-2}$. For cell 1 and cell 2 the cell voltage at $2 \mathrm{~A} \mathrm{~cm}^{2}$ decreases by $\left.4 \mathrm{mV}\left(\Delta E_{E-j(60}{ }^{\circ} \mathrm{C}\right) / \Delta t=-13 \mu \mathrm{V} \mathrm{h}^{-1}\right)$ and increases by $176 \mathrm{mV}$ $\left.\left(\Delta E_{E-j(60}{ }^{\circ} \mathrm{C}\right) / \Delta t=+595 \mu \mathrm{V} \mathrm{h}^{-1}\right)$, respectively, comparing polarization from BoT with EoT (end of test) at an operating temperature of $60{ }^{\circ} \mathrm{C}$. When comparing the cell voltage from BoT to EoT from the polarization curve at $100{ }^{\circ} \mathrm{C}$ for cell 2 a decrease of $\left.102 \mathrm{mV}\left(\Delta E_{E-j(100}{ }^{\circ} \mathrm{C}\right) / \Delta t=+346 \mu \mathrm{V} \mathrm{h}^{-1}\right)$ is observed. The voltage loss rates for cell 1 and 2 for the constant current experiment and the polarization curves at BoT are listed in Table I.

The lower cell voltage at a higher operating temperature in comparison to lower operating temperature for cell 2 in Figs. 1a and $1 \mathrm{~b}$ can be explained by a decrease in cell loss contributions observed at a higher PEWE operating temperature. ${ }^{5}$ In Fig. $1 \mathrm{~b}$ at a current density of $8 \mathrm{~mA} \mathrm{~cm}^{-2}$ the cell voltage is $84 \mathrm{mV}$ lower for cell 2 (BOT) at $100{ }^{\circ} \mathrm{C}$ than at $60{ }^{\circ} \mathrm{C}$. By subtracting the ohmic overpotential and the kinetic overpotential from the cell voltage, a voltage difference of $40 \mathrm{mV}$ is obtained, which agrees well with the voltage difference predicted by the Nernst equation of $31 \mathrm{mV}$. The decrease in cell voltage results in an efficiency increase of $5 \%$ at $2 \mathrm{~A} \mathrm{~cm}^{-2}$. The higher voltage loss rate observed at higher operating temperature agrees well with the assumption of an increased detrimental impact of the operating temperature on the cell components and, consequently, on the cell performance. In literature, voltage loss rates are either calculated from the mean loss rate of cell voltage over the experimental duration ${ }^{8,14,18,30-33}$ or from the difference in cell voltage in the polarization curve at a specific current density. ${ }^{11,13}$ For cell 1 the voltage loss rate decreases from $\Delta E_{j=\text { const }} / \Delta t=+29 \mu \mathrm{V} \mathrm{h}^{-1}$ during the constant current experiment to $\left.\Delta E_{E-j(60}{ }^{\circ} \mathrm{C}\right) / \Delta t=-13 \mu \mathrm{V} \mathrm{h}^{-1}$ for the voltage difference extracted from polarization curves. However, for cell 2 the voltage loss rate increases from $\Delta E_{j=\text { const }} / \Delta t=+126 \mu \mathrm{V} \mathrm{h}^{-1}$ during the constant current experiment to $\Delta E_{E-j\left(100{ }^{\circ} \mathrm{C}\right)} / \Delta t=+346 \mu \mathrm{V} \mathrm{h}^{-1}$ for the voltage difference extracted from polarization curves at $100{ }^{\circ} \mathrm{C}$. The rate of voltage change increases to $\Delta E_{E-j\left(60{ }^{\circ} \mathrm{C}\right)} / \Delta t=+598 \mu \mathrm{V}$ $\mathrm{h}^{-1}$ when comparing the polarization curves of cell 2 at $60{ }^{\circ} \mathrm{C}$.

The constant current experiment was followed by a break of about 30 min to switch from the DC power supply to the Biologic potentiostat before polarization curves were recorded. During this interruption the cells were maintained at the operation temperature. Since the water drag through the membrane was missing during this period, the membrane of cell $2\left(100{ }^{\circ} \mathrm{C}\right)$ could have dried out. This would lead to a decrease in CL-PTL compression and a loss of interfacial contact and, as a result, an increase of all overpotentials. ${ }^{34}$ Similar to the reversible degradation of cell 1, Rakousky et al. observed after a current interruption of $5 \mathrm{~min}$ of an electrolysis cell operated at $2 \mathrm{~A} \mathrm{~cm}^{-2}$ and $80{ }^{\circ} \mathrm{C}$ a cell voltage recovery of $60 \%{ }^{13}$ However, the phenomena of reversible degradation cannot be explained yet.

Figure 1c and Table II show the voltage loss rates of cell 1 and cell 2 in comparison to other single cell results from literature data degraded under constant current or constant voltage operating procedures at different operating temperatures. The mean voltage loss rates of the cells generally increase with operating temperature, as expected. Comparing the different studies on PEWE cell degradation performed at different operation temperatures, PEWE operation shows low voltage loss rates at $60{ }^{\circ} \mathrm{C}$ (average of $16 \mu \mathrm{V}$ $\mathrm{h}^{-1}$ ) and moderate voltage loss rates at a temperature of $80{ }^{\circ} \mathrm{C}$ (average of $24 \mu \mathrm{V} \mathrm{h}^{-1}$ ). At elevated temperature PEWE operation, the voltage loss rate increases by an order of magnitude. An Arrhenius analysis of the voltage loss rates of Fig. 1c gives an apparent activation energy of $E_{a p p}^{a}=68 \pm 21 \mathrm{~kJ} \mathrm{~mol}^{-1}$ and agrees well with data reported in the literature $\left(E_{a p p}^{a}=56 \mathrm{~kJ} \mathrm{~mol}^{-1}{ }^{16}\right.$ $E_{\text {app }}^{a}=75 \mathrm{~kJ} \mathrm{~mol}^{-135}$ ).

Efficiency loss is caused by material aging and degradation. ${ }^{36,37}$ An overpotential analysis aims to give an insight into the underlying degradation effects. By performing a cell voltage breakdown (section 2.6), the iR-free polarization curve in Fig. 2a the overpotentials (Fig. 2b) and the overpotential specific voltage loss rates were calculated (Fig. 2c). A decrease in kinetic overpotential $\left(-44 \mu \mathrm{V} \mathrm{h}^{-1}\right)$ and mass transport overpotential $\left(-23 \mu \mathrm{V} \mathrm{h}^{-1}\right)$ of cell 1 was offset by an increase in the ohmic overpotential 

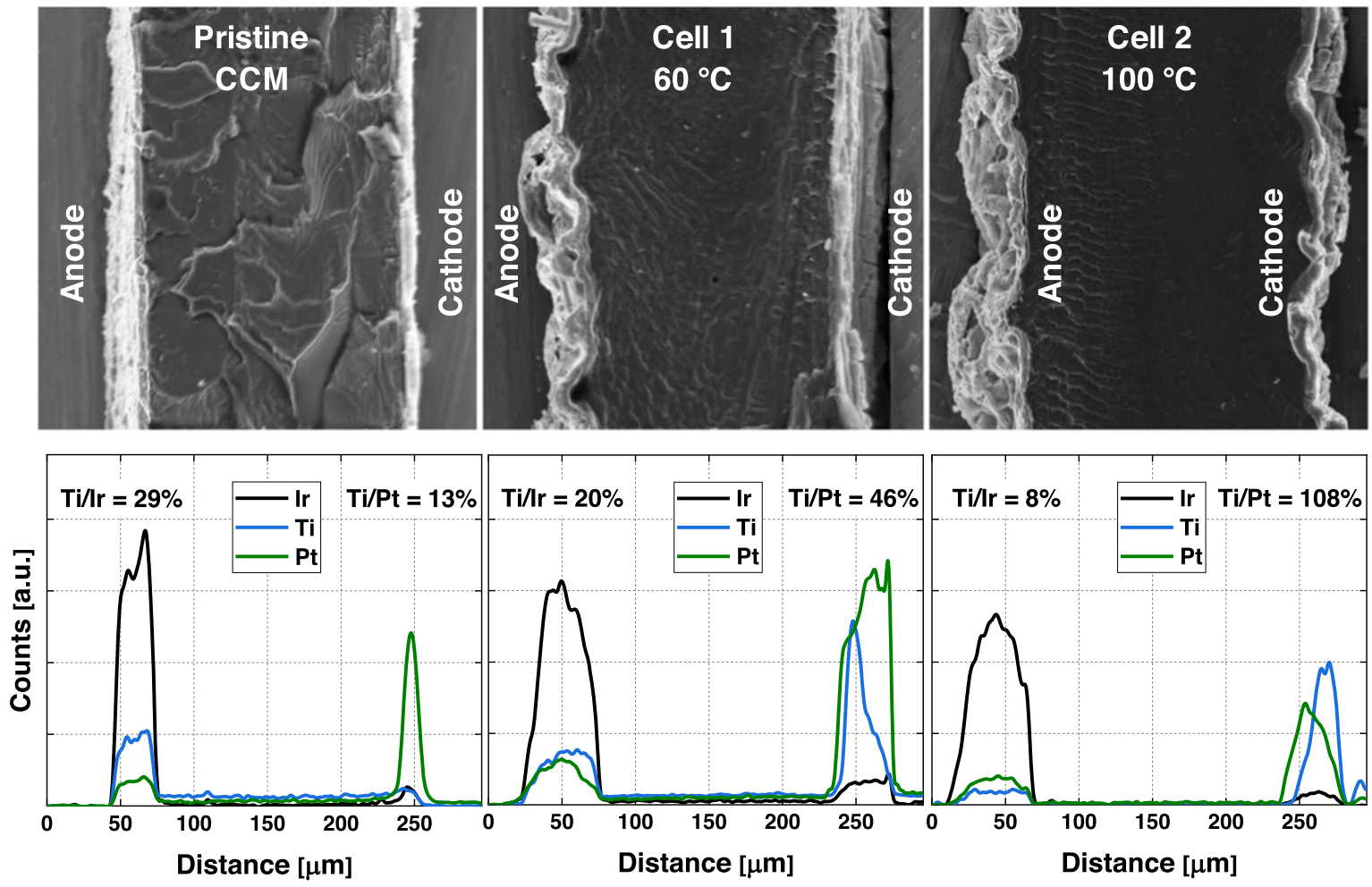

Figure 5. Scanning electron miscoscopy images (top) and corersponding energy dispersive X-ray elemental mapping (bottom) for iridium (Ir), titanium (Ti) and platinum $(\mathrm{Pt})$ of catalyst coated membrane $(\mathrm{CCM})$ cross-sections of a pristine $\mathrm{CCM}$ (left), cell 1 (aged at $60{ }^{\circ} \mathrm{C}$, center) and cell 2 (aged at $100{ }^{\circ} \mathrm{C}$, right). The integrated peak ratio of titanium to iridium as well as platinum to titanium is indicated on top of the peaks coresponding to anode and cathode catalyst layer, respecitvely.

$\left(+26 \mu \mathrm{V} \mathrm{h}^{-1}\right)$ and the proton transport overpotential $\left(+28 \mu \mathrm{V} \mathrm{h}^{-1}\right)$, which explains the similar polarization curves before and after the experiment. For cell 2 ohmic overpotential $\left(+324 \mu \mathrm{V} \mathrm{h}^{-1}\right)$, kinetic overpotential $\left(+294 \mu \mathrm{V} \mathrm{h}^{-1}\right)$ and anode proton transport overpotential $\left(+37 \mu \mathrm{V} \mathrm{h}^{-1}\right)$ increased and only the mass transport overpotential $\left(-69 \mu \mathrm{V} \mathrm{h}^{-1}\right)$ decreased. Especially the large increase in kinetic overpotential and ohmic overpotential has a strong impact on PEWE performance loss at elevated operating temperatures. Frensch et al. report an increase of $219 \mu \mathrm{V} \mathrm{h}^{-1}$ for the ohmic overpotential at an operating temperature of $90{ }^{\circ} \mathrm{C}$ and an experimental duration of $500 \mathrm{~h} .^{9}$ However, a decrease of non-ohmic overpotentials $\left(-80 \mu \mathrm{V} \mathrm{h}^{-1}\right)$ was observed. Degradation studies at an operating temperature of $80{ }^{\circ} \mathrm{C}$ report ohmic overpotential voltage loss rates between +24 and $+52 \mu \mathrm{V} \mathrm{h}^{-1}$ and smaller nonohmic overpotential voltage loss rates of -28 to $+24 \mu \mathrm{V} \mathrm{h}^{-1}$. $9,11,13$

Anode catalyst layer degradation.-Kinetic overpotentials mainly stem from the sluggish OER and are related to the activity and number of active sites on the anode catalyst surface. ${ }^{38}$ As such an increase in kinetic overpotential is associated with degradation of the anode catalyst layer. Figure 3 shows the cyclic voltammograms of the anode catalyst layer under $\mathrm{N}_{2} / \mathrm{H}_{2}$ half-cell conditions. The curves of cell 1 and cell 2 at BoT are similar. The integrated charge (CV between $0.8-1.2 \mathrm{~V}$ ) of cell 1 after aging increases by $2 \%$ whereas for cell 2 it decreases by $49 \%$. The charge in the CVs can be directly correlated to the available catalyst sites on the electrode surface. ${ }^{39}$ Figure 4 a shows the anode catalyst layer (CLs) thickness of cell 1 and cell 2 at EoT in comparison to a pristine CCM. For cell 1 , the average of the CL thickness decreases by $7 \%$ and for cell 2 by $24 \%$ in comparison to the pristine CCM. Further, an increase in the width of the thickness distribution for both cells in comparison to the pristine CCM is observed. This increase is higher for cell 2 than cell 1. It seems that a low decrease in anode CL thickness by $7 \%$ like for cell 1 does not impact the activity whereas a higher decrease in thickness by $24 \%$ like for cell 2 is critical for the activity. The decrease in the number of anode CL active sites can be explained by $\mathrm{IrO}_{2}$ dissolution or detachment. ${ }^{37}$

A locally thin catalyst layer can lead to reduced in-plane electronic conductivity as well as increased PTL-catalyst layer interfacial resistance contributing to an increase in ohmic and kinetic overpotential. ${ }^{39,40}$

Anode catalyst layer deformation.-PEWE cell compression leads to deformation of the CL due to mechanical stress and partial intrusion of the ionomer into the PTL. Mechanical stress was shown to reduce $\mathrm{CCM}$ thickness and increase kinetic overpotentials. ${ }^{14}$ Ionomer creep is enabled by the coarse PTL on the anode site with an average surface pore diameter of $50 \mu \mathrm{m}$ and a nominal thickness variation of $5 \mu \mathrm{m} .{ }^{41}$ Figures $4 \mathrm{a}$ and $4 \mathrm{~b}$ show that the width of the thickness distributions of the membrane and the anode catalyst layers increase more for cell 2 than for cell 1. A higher degree of swelling of the membrane with increasing temperature would increase the compression of the catalyst layer towards the PTL. The operating temperature of cell $2\left(100^{\circ} \mathrm{C}\right)$ is closer to the glass transition temperature of Nafion $\left(110^{\circ} \mathrm{C}\right)$ leading to stronger creep of the ionomer in the membrane as well as in the catalyst layer. ${ }^{42}$ Hinatsu et al. found an increase in water uptake by $50 \%$ for N117 membranes immersed in water by increasing the water temperature from 60 to $100{ }^{\circ} \mathrm{C} .^{43}$ This could lead to larger compression of the $\mathrm{CL}$ towards the PTL for cell 2. Deformation of the catalyst layer can lead to breaks in the proton transport pathway and in consequence an increase in anode proton transport resistance. ${ }^{14}$ Further, it results in microcracks in the CL that cause higher in-plane resistances. ${ }^{34}$

Anode catalyst layer dissolution.-Dissolved ions from the catalyst layer can either be taken up by the circulating water in the anode gas-water loop or by the surrounding ionomer in the CL as well as the membrane ionomer. ${ }^{44}$ Figure 5 shows the EDX counts for cross-sectional CCM mappings. The ratio of titanium to iridium on the anode catalyst layer and the ratio of titanium to platinum on 

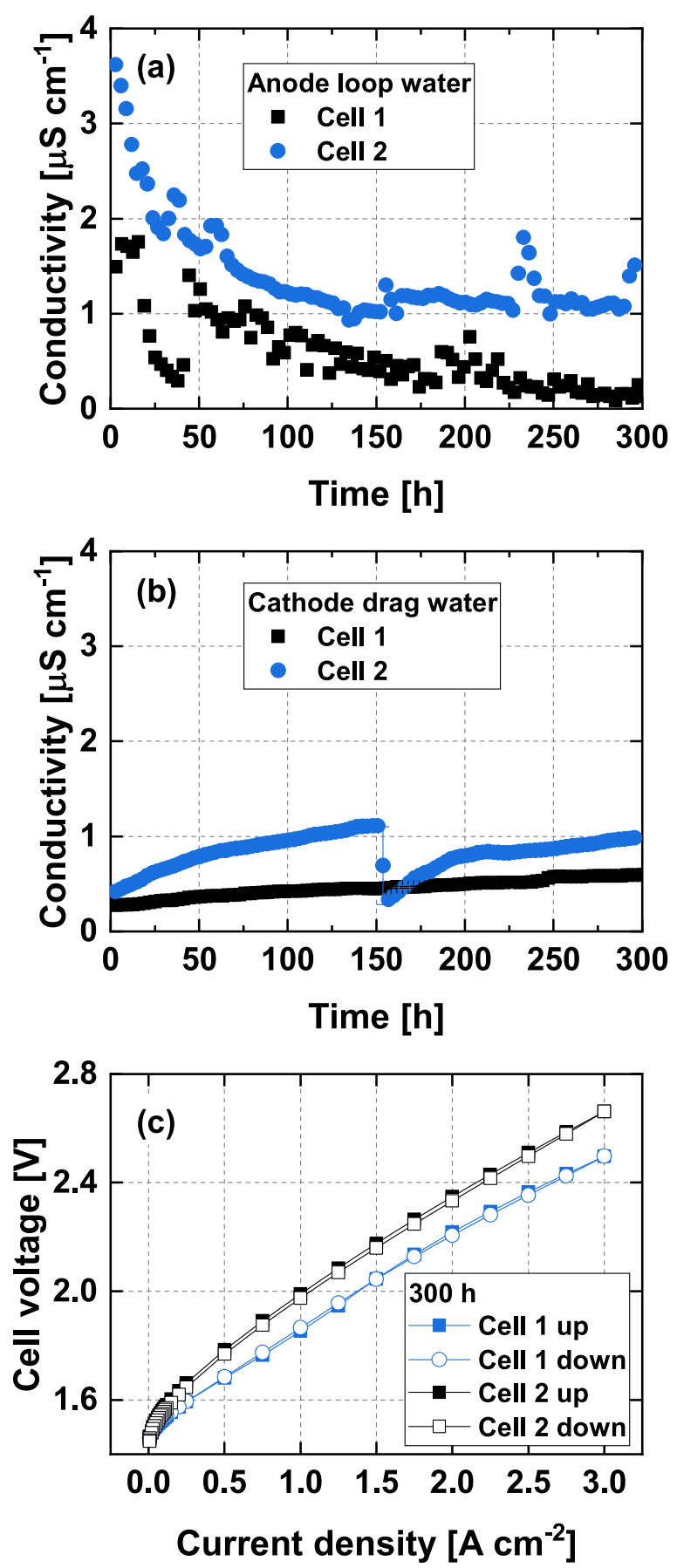

Figure 6. (a) Conductivity of the anode water loop as a function of the experimental time and (b) conductivity of the cathode drag water for cell 1 (aged at $60{ }^{\circ} \mathrm{C}$, black), cell 2 (aged at $100{ }^{\circ} \mathrm{C}$, blue) (c) Up- (filled symbols) and down-scan (empty symbols) of a polarization curve at EoT for cell 1 (aged at $60{ }^{\circ} \mathrm{C}$, black squares) at $60{ }^{\circ} \mathrm{C}$ and cell 2 (aged at $100{ }^{\circ} \mathrm{C}$, blue circles) at $100{ }^{\circ} \mathrm{C}$.

the cathode catalyst layer for a pristine CCM, cell 1 and cell 2 was calculated. On the anode catalyst layer of the pristine CCM the Ti/Ir ratio is highest (29\%), followed by $20 \%$ for cell 1 and $8 \%$ for cell 2 at EoT. The Ti content in the anode CL dropped in both cells, and a higher loss is observed for operation at elevated temperature. In the cathode CL the Ti/Pt ratio is $13 \%$ for the pristine CCM, $46 \%$ for cell 1 and $108 \%$ for cell 2 after the test. The presence of $\mathrm{Ti}$ in the cathode catalyst layer of the pristine membrane could be explained by contamination of $\mathrm{Ti}$ during the SEM sample preparation. The decreasing titanium/iridium ratio in the anode catalyst layer suggests titanium loss in the anode CL for cell 1 and cell 2, however a 3 times higher Ti loss was detected for cell 2 . This indicates that the missing $\mathrm{TiO}_{2}$ support plays a role in anode catalyst activity degradation of cell 2 . The increase in titanium/platinum ratio in the cathode catalyst layer points towards Ti dissolution followed by Ti ion migration and/ or diffusion from anode to cathode which is in line with literature. ${ }^{13}$ The decreasing $\mathrm{Ti} / \mathrm{Ir}$ ratio indicates a Ti loss in the anode $\mathrm{CL}$ but does not exclude Ir loss. However, the Ir/Pt ratio for the cathode was not found to be increased neither for cell 1 nor for cell 2, which would exclude Ir dissolution combined with migration/diffusion from anode to cathode.

The conductivity of the anode loop water is shown in Fig. 6a. Initially $1.7 \mu \mathrm{S} \mathrm{cm}^{-1}$ were measured for cell 1 . The value decreases to a level of $0.2 \mu \mathrm{S} \mathrm{cm} \mathrm{cm}^{-1}$ at $300 \mathrm{~h}$. The conductivity in the anode loop for cell 2 has an initial value of $3.6 \mu \mathrm{S} \mathrm{cm}^{-1}$, which decreases to $1.0 \mu \mathrm{S} \mathrm{cm}^{-1}$ at $150 \mathrm{~h}$ and remains at that level until the end of the experiment. The conductivity can be directly linked to the content of ions in the system. The concentration of ions in the anode water loop decreases for both cells over the duration of the experiment because an ion exchange resin is included into the anode loop. The higher initial concentration for both cells in comparison to the value at the end of the experiment could be related to the loss of constituents and contamination from the cell assembly as well as test bench components in the initial phase. ${ }^{14}$ By integrating the conductivity over the whole period of the experiment, the estimated total number of ions released by the anodic PEWE system is 2.5 times higher for cell 2 than for cell 1 . For cell 2 the ion release rate by the CCM seems to be in an equilibrium with the rate of ion scavenging by the ion exchange resin from $150 \mathrm{~h}$ until the end of test. In contrast, the ion content related to cell 1 deceases until the end of the experiment. The increase in conductivity in the anode water loop supports the theory of ion dissolution into the water.

In order to investigate CL dissolution under the impact of temperature, a thermal stress test was conducted. Table III shows the dissolution of iridium, titanium and platinum of a CCM in an acidic environment during a thermal stress test (TST) at $60{ }^{\circ} \mathrm{C}$ and $100{ }^{\circ} \mathrm{C}$ compared to the loss from the CCM of cell 1 and cell 2 as well as to catalyst durability in a scanning flow cell coupled to ICPOES from literature. The TST shows a very low solubility of $\mathrm{TiO}_{2}$ and $\mathrm{IrO}_{2}$ in acid, which is in agreement with literature. ${ }^{45}$ Iridium and titanium dissolution increases at elevated temperature (Ir: 13\%, Ti: $4 \%$ ).

$\mathrm{IrO}_{2}$ nanoparticle dissolution rate was found to be dependent on the potential applied to the electrode. ${ }^{48}$ Scanning flow cell experiments (SFC) at constant current and a resulting voltage of $1.6 \mathrm{~V}$ with the same catalyst as used in this study showed an Ir dissolution 6 times higher than what was found in the TST. ${ }^{46,47}$ However, Ti dissolution was found to be 2 orders of magnitude higher in the SFC experiment than under the influence of pure thermal stress in the TST. Voltage appears to be a higher stressor for anode CL nanoparticles than temperature, especially for the $\mathrm{TiO}_{2}$ support. This contradicts the higher CL degradation of $100 \mathrm{mV}$ and a $40 \mathrm{mV}$ lower iR-free voltage, respectively, measured at $60{ }^{\circ} \mathrm{C}$ of cell 2 (aged at $100{ }^{\circ} \mathrm{C}$ ) in comparison to cell 1 (aged at $60^{\circ} \mathrm{C}$ ). According to the Pourbaix diagram, titanium should be passivated at $\mathrm{pH}=0$ and the voltage range of the anode in PEWE. ${ }^{49}$ It appears that the combination of elevated temperature and voltage stress is detrimental for Ti dissolution on the anode. CL supports that are more resistant against dissolution, such as $\mathrm{W}$ and $\mathrm{Nb}$, have to be integrated into the $\mathrm{CL}$ to enable elevated temperature operation. ${ }^{50,51} \mathrm{IrO}_{2}$ anode catalyst materials lacking a support showed voltage loss rates that were an order of magnitude higher. ${ }^{32}$ To the best of our knowledge there is no literature data on iridium and titanium dissolution in SFCs at elevated temperature at representative PEWE anode potentials.

Anode catalyst layer detachment.-It has been reported that membrane swelling and gas bubble formation strongly support anode catalyst particle detachment. ${ }^{52-55}$ Recently, Panchenko et al. 
Table III. Dissolution rate of iridium, titanium and platinum of catalyst coated membranes $(\mathrm{CCMs})$ aged at $60^{\circ} \mathrm{C}(\mathrm{Cell} 1)$ and at $100{ }^{\circ} \mathrm{C}(\mathrm{Cell} 2)$ calculated from the thickness loss of the catalyst layer at the end of the degradation experiment (EoT) in comparison to the thickness of a pristine CCM (Fig. 4), assuming equal dissolution for all elements (Column CCM EoT). Solution analysis by inductively coupled plasma mass spectroscopy (ICP-MS) of a thermal stress test (TST) on CCMs aged at $60^{\circ} \mathrm{C}$ (Cell 1) and at $100{ }^{\circ} \mathrm{C}$ (Cell 2) in $1 \mathrm{M} \mathrm{H}_{2} \mathrm{SO}_{4}(\mathrm{Column}$ CCM TST). Solution analysis by ICP-MS of catalysts aged in a scanning flow cell (SFC) coupled to an ICP-MS at constant current and a potential of about $1.6 \mathrm{~V}$ (Column SFC).

\begin{tabular}{|c|c|c|c|c|c|c|c|c|}
\hline \multirow{3}{*}{$\mathrm{T}\left[{ }^{\circ} \mathrm{C}\right]$} & \multicolumn{8}{|c|}{ Dissolution rate $\left[\mathrm{pg} \mathrm{cm}^{-2} \mathrm{~h}^{-1}\right] /$ loss in comparison to initial pristine catalyst layer thickness } \\
\hline & \multicolumn{3}{|c|}{ Iridium } & \multicolumn{3}{|c|}{ Titanium } & \multicolumn{2}{|c|}{ Platinum } \\
\hline & CCM EoT & CCM TST & $\mathrm{SFC}^{46}$ & CCM EoT & CCM TST & $\mathrm{SFC}^{46,47}$ & CCM EoT & CCM TST \\
\hline 25 & - & - & $560 / 0.01 \%{ }^{\mathrm{b})}$ & - & - & $9,800 / 1.6 \%{ }^{\text {b) }}$ & - & - \\
\hline 60 & $320,000^{\mathrm{a})} / 6.7 \%$ & $85 /<0.01 \%{ }^{\mathrm{b})}$ & - & $33,000^{\mathrm{a})} / 6.7 \%^{\mathrm{b})}$ & $62 /<0.01 \%^{\mathrm{b})}$ & - & $96,000^{\mathrm{a})} / 7.0 \%$ & $28,000 / 2.1 \%^{\mathrm{b})}$ \\
\hline 100 & $930,000^{\mathrm{a})} / 24 \%$ & $96 /<0.01 \%^{\mathrm{b})}$ & - & $96,000^{\mathrm{a})} / 24 \%^{\mathrm{b})}$ & $65 /<0.01 \%^{\mathrm{b})}$ & - & $240,000^{\mathrm{a})} / 18 \%$ & $32,000 / 2.4 \%^{\mathrm{b}}$ \\
\hline
\end{tabular}

a) Calculated from thickness loss in comparison to a pristine CCM assuming equal dissolution of elements. b) Calculated applying the dissolution rate on the loading of a pristine CCM.

found in an operando investigation that oxygen gas bubble formation represents the driving force for anode CL detachment. ${ }^{55}$ The oxygen was generated at the CL-membrane interface. The study revealed that the anode CL loading of a CCM coated with a commercial $\mathrm{IrO}_{2}$ (loading: $2.2 \mathrm{mg} \mathrm{cm}^{-2}$ ) was reduced by $60 \%$ during the first $10 \mathrm{~h}$ of operation. The detached particles were found to have the same size distribution as the catalyst powder used to produce the CL (mean particle diameter of $5 \mu \mathrm{m}$ ) and could therefore escape through the PTL into the anode water loop. However, the operating temperature was not mentioned in their study. The catalyst particles used in our study have been analyzed by and van Pham et al. and showed particle sizes of $100 \mathrm{~nm}{ }^{46}$ These catalyst particles could escape through the PTL, too. The volumetric production rate of gas at the anode is $37 \%$ higher at $100{ }^{\circ} \mathrm{C}$ than at $60{ }^{\circ} \mathrm{C}$ at $2 \mathrm{~A} \mathrm{~cm}^{-2}$ due to the increased water vapor pressure (detailed explanation in Supplemental Material). The oxygen saturation of the anode inlet flow can be assumed to be $100 \%$ for both temperatures. ${ }^{56}$ A higher volumetric gas production rate could therefore be a reason for increased CL particle detachment. The lower CL thickness reduction in comparison to Ref. 55 could be due to the $\mathrm{IrO}_{2}$ supported on $\mathrm{TiO}_{2}$ catalysts used in this work which was found to be more stable, due to an anchoring effect of $\mathrm{IrO}_{2}$ on $\mathrm{TiO}_{2} \cdot{ }^{32,57}$ Therefore, a reduced $\mathrm{TiO}_{2}$ content on the anode CL, because of the observed $\mathrm{Ti}$ dissolution, could also be a reason for higher $\mathrm{IrO}_{2}$ detachment at elevated temperature. Whereas dissolution can be considered as the dominant degradation cause for $\mathrm{TiO}_{2}$, detachment could be more critical for $\mathrm{IrO}_{2}$. So far, the detailed mechanism for CL particle detachment remains unanswered. Especially the involvement of $\mathrm{TiO}_{2}$ into the $\mathrm{CL}$ detachment needs to be investigated further.

Cathode catalyst degradation.-Figure $4 \mathrm{~b}$ shows the cathode CL thickness distribution for cell 1 and cell 2 at EoT in comparison to a pristine CCM. Assuming the thickness to be proportional to the loading of the CL, for cell 1 the CL loading decreases by $8 \%$ and for cell 2 by $22 \%$ in comparison to the pristine CCM, which is similar to the values recorded for the anode.

The conductivity of the cathode drag water is at $0.36 \mu \mathrm{S} \mathrm{cm}^{-1}$ at BoT for both cells and increases to a level of $0.6 \mu \mathrm{S} \mathrm{cm}^{-1}$ for cell 1 and $1.0 \mu \mathrm{S} \mathrm{cm}^{-1}$ for cell 2 (Fig. 6b). This suggest a higher rate of ionic dissolution into the cathodic water at elevated temperatures. Analysis of the cathode drag water collected during the experiment by ICP-MS showed neither Pt nor Ti nor Ir above the detection limit. The missing evidence of $\mathrm{Ti}$ in the cathode drag water suggests that the ionomer of the $\mathrm{CL}$ is binding the Ti ions, which is supported by the EDX elemental mapping (Fig. 5). The increase in conductivity in cathodic drag water could be also caused by ions that stem from test system impurities, like $\mathrm{Al}$ and $\mathrm{Fe}$.

Pt dissolution and migration is a well-known issue in the polymer electrolyte fuel cell community. The rate increases by a factor of then 10 when exposed to an oxidative voltage $(>0.8 \mathrm{~V}),{ }^{58}$ which is not the case for the PEWE cathode.
The Pt concentration in acidic environment from the TST was found to be about 3 orders of magnitude higher than for titanium and iridium (Table III). This contradicts to observations reported in the literature in which the dissolution rate of platinum black was reported to be around $60 \mathrm{pg} \mathrm{h}^{-1} \mathrm{~cm}^{-2}$ at $60{ }^{\circ} \mathrm{C}$ in $1 \mathrm{M} \mathrm{H}_{2} \mathrm{SO}_{4}{ }^{59}$ However, $\mathrm{Pt} / \mathrm{C}$ has a much higher surface area than Pt black making it more prone to dissolution. The presence of oxygen in the sample bottles could have caused a local potential increase to $1 \mathrm{~V}$ that could oxidize the $\mathrm{Pt}$ thus facilitating dissolution. While $\mathrm{IrO}_{2}$ particle detachment was found to decrease the anode CL thickness by $60 \%$ in the first hours of operation, no decrease was observed for the $\mathrm{Pt} / \mathrm{C}$ containing cathode CL. ${ }^{55}$

Membrane.-Contamination.-An increasing amount of metal ions in the system as well as in the catalyst layer points to an increased amount of ions in the membrane. ${ }^{44,60}$ This is supported by the large increase of ohmic overpotential for cell 2 in comparison to cell 1 (Fig. 2). Similar to the ionomer in the catalyst layer, the ion exchange groups in the membrane can exchange contaminant ions for protons leading to a lower conductivity and a higher ohmic resistance. However, no significant quantities of Ir, Pt and Ti could be detected in the membranes of cell 1 and cell 2 by EDX analysis. (Fig. 5). By performing an up and down scan of the polarization curve, the presence of contaminants can be detected by the appearance of a hysteresis in the voltage response. ${ }^{44}$ The polarization curve of cell 1 and cell 2 showed no such hysteresis (Fig. 6c). A cationic contamination of cell 1 and cell 2 can therefore be excluded.

Gas permeation.-Figure 7a shows the hydrogen content in oxygen in the anode compartment for cell 1 and cell 2 . The value for cell 1 is $0.40 \%$ on average (at $60{ }^{\circ} \mathrm{C}$ ) and for cell $20.92 \%$ (at $100{ }^{\circ} \mathrm{C}$ ). The observed values for cell 1 agrees well with literature. ${ }^{61}$ The increase in hydrogen content with temperature can be associated to the higher rate of hydrogen permeation through the membrane at elevated temperature. ${ }^{62}$ The oxygen permeation is about a factor of 2 smaller than the hydrogen permeation due the lower permeability of Nafion for oxygen. ${ }^{62}$ Gas permeation could be lowered by gas crossover suppression e.g. using a recombination agent like $\mathrm{Pt}$ that catalyzes $\mathrm{O}_{2}$ and $\mathrm{H}_{2}$ recombination ${ }^{63}$ or by use of membranes that have lower gas permeability coefficients. ${ }^{23,29,64,65}$

Membrane decomposition.-Chemical ionomer decomposition can be monitored by determination of the fluoride release rate (FRR) that was measured at the cathode compartment outlet (Fig. 7b). ${ }^{26}$ Both cells show similar FRR at the beginning of the experiment $\left(\sim 0.4 \mu \mathrm{g} \mathrm{cm}^{-2} \mathrm{~h}^{-1}\right)$. During the experiment the FRR decreases for cell $1\left(\sim 0.07 \mu \mathrm{g} \mathrm{cm}^{-2} \mathrm{~h}^{-1}\right.$ at $\left.300 \mathrm{~h}\right)$ yet increases for cell $2\left(\sim 0.69 \mu \mathrm{g} \mathrm{cm}^{-2} \mathrm{~h}^{-1}\right.$ at $\left.300 \mathrm{~h}\right)$. The high initial FRR for cell 1 could be a result of membrane break-in. $9,14,66$

The integrated FRR for cell 1 and cell 2 was three orders of magnitude higher than for the two pristine N117 membranes 

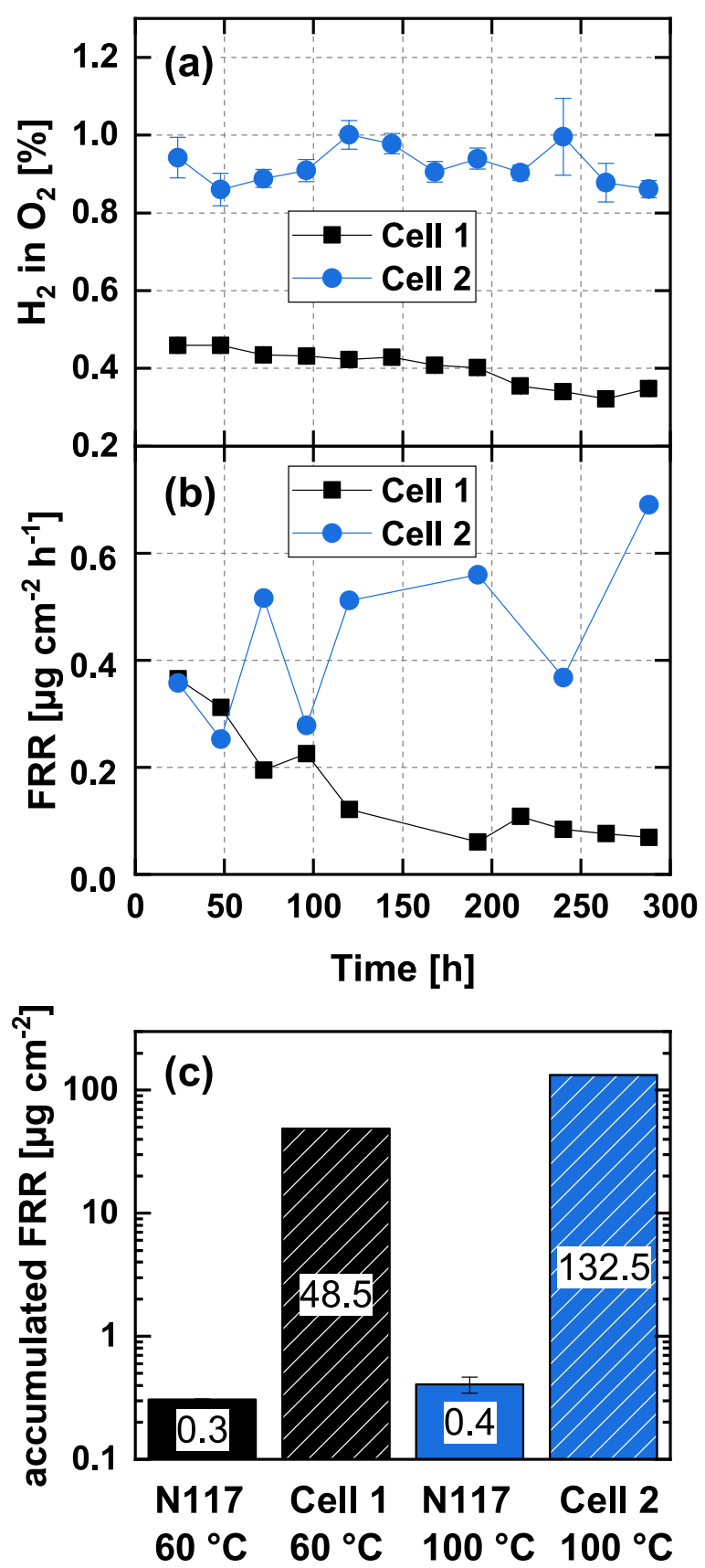

Figure 7. (a) Hydrogen content in oxygen in the anode compartment for cell 1 (aged at $60^{\circ} \mathrm{C}$, black), cell 2 (aged at $100{ }^{\circ} \mathrm{C}$, blue). (b) Flouride release rate (FRR) in the periodically discarded cathode drag water for cell 1 (aged at $60{ }^{\circ} \mathrm{C}$, black), cell 2 (aged at $100{ }^{\circ} \mathrm{C}$, blue). (c) Accumulated fluoride release rate (FRR) over the degradation experiment for cell 1 and cell 2 as well as for a thermal stress test of Nafion N117 in deionized water at $60{ }^{\circ} \mathrm{C}$ and at $100{ }^{\circ} \mathrm{C}$.

exposed to a thermal stress test in DI water at $60{ }^{\circ} \mathrm{C}$ and $100{ }^{\circ} \mathrm{C}$ respectively (Fig. 7c). An increase by only $0.1 \mu \mathrm{g} \mathrm{cm}^{-2}$ is noted for an increase from $60{ }^{\circ} \mathrm{C}$ to $100{ }^{\circ} \mathrm{C}$ for the pristine membranes. Pure exposition to water and oxygen at elevated temperature does not have a high impact on membrane decomposition in comparison to exposition to PEWE conditions which is in agreement with literature. ${ }^{17}$ An increase in temperature from 60 to $100{ }^{\circ} \mathrm{C}$ under PEWE conditions increases ionomer decomposition by almost a factor of three over a $300 \mathrm{~h}$ operation time.

Radical formation and, as a result, membrane decomposition is accelerated by higher oxygen gas permeation rates. ${ }^{17,26,67}$ Permeated oxygen can react with hydrogen on the cathode Pt catalyst to hydrogen peroxide. Hydrogen peroxide decomposes to radicals that attack the polymer backbone of the ionomer. ${ }^{26}$

The FRR for cell 1 , aged at $60{ }^{\circ} \mathrm{C}$, agrees well with literature for N115 membranes that are operated at ambient pressure. ${ }^{9,14}$ In 2006, LaConti et al. reported that the rate of chemical decomposition of a Nafion ${ }^{\circledR} 117$ membrane increased by 2 orders of magnitude upon increase of the operating temperature from 60 to $149{ }^{\circ} \mathrm{C}$, and the projected lifetime of the cell being reduced by the same factor. ${ }^{16}$ The development of chemically more stabilized perfluorinated membranes in the last decade has reduced the amount of reactive end groups in Nafion. ${ }^{68}$ However, chemical stabilization of Nafion ionomer does not prevent fluoride release. Recently, Frensch et al. found a 40-fold increased extent of chemical decomposition in PEWE using a N115 membrane when increasing the operating temperature from $60{ }^{\circ} \mathrm{C}$ to $90{ }^{\circ} \mathrm{C} .{ }^{9}$ The FRR of cell 2, operated at $100{ }^{\circ} \mathrm{C}$, is lower by more than a factor of 2 compared to the FRR reported at an operating temperature of $90{ }^{\circ} \mathrm{C}$ after $300 \mathrm{~h} .{ }^{9}$ Membrane thickness as well as gas pressure contribute to membrane gas permeability. ${ }^{69,70}$ The difference could be explained by the higher gas crossover observed with thinner membranes. More recently, Marocco et al. showed that the FRR is 6 times higher for a PEWE cell operated at $80{ }^{\circ} \mathrm{C}$ than at $60{ }^{\circ} \mathrm{C} .{ }^{25}$

Moreover, in addition to general thermal activation, metal impurities in the catalyst layers, which were found to be higher in cell 2, promote radical formation and therefore membrane degradation. ${ }^{22}$ It has been reported that fluoride ions in the ppm range can destroy titanium oxide and release Ti ions. ${ }^{71-73}$ The Ti ions are Fenton active, promoting radical formation which would constitute an autocatalytic degradation mechanism that agrees well with high $\mathrm{Ti}$ dissolution rates at elevated temperature operation observed in this work. ${ }^{74}$ The accumulating $\mathrm{Ti}$ ions could then contribute to an increase in FRR over time for cell 2 which was also observed by Frensch et al..

The membrane thickness analysis based on SEM images of cell 1 and cell 2 is displayed in Fig. 4c. The average membrane thickness for cell 1 is higher than for cell 2 . This could be due to the larger extent of chemical degradation and related ionomer decomposition at elevated temperatures. ${ }^{17}$ However, both membranes yield larger average thicknesses than the pristine thickness of $180 \mu \mathrm{m}$ of a Nafion N117 (membrane at 25\% relative humidity). Lettenmeier et al. found an increase of the average membrane thickness of $7 \%$ and $13 \%$ for two cells operated for a total of $800 \mathrm{~h}$ and a temperature of $60{ }^{\circ} \mathrm{C} .{ }^{75}$ In their study, no explanation for this phenomenon was given. The observation could be related to a strain-based memory effect that has been observed for Nafion exposed to elevated temperatures. ${ }^{76}$ By heating up the ionomer above its shape memory transition temperature and applying a deformation, the shape is partially maintained upon cooling.

Porous transport layer and flow fields.-Titanium passivation.-Increases of ohmic overpotentials are largely influenced by the passivation of the Ti PTL as well as the Ti flow fields on anode and cathode. ${ }^{9,13,40} \mathrm{Ti}$ components exposed to a low $\mathrm{pH}$, high humidity, oxygen rich environment and potentials in the range of the anode can lead to the generation of $\mathrm{TiO}_{2}$ films. ${ }^{77} \mathrm{Lu}$ et al. observed that $\mathrm{Ti}$ passivation is increased in an oxygen/ water environment when increasing the temperature from 50 to $100{ }^{\circ} \mathrm{C}^{78}$ This would fit well to the higher ohmic overpotentials observed for cell $2\left(100^{\circ} \mathrm{C}\right)$ in comparison to cell $1\left(60^{\circ} \mathrm{C}\right)$. Use of protective layers on the PTL surface that are more stable against passivation such as $\mathrm{Ir}^{79}$ were found to reduce $\mathrm{Ti}$ passivation and could help to reduce ohmic overpotentials at elevated temperatures.

Titanium dissolution.-A higher $\mathrm{Ti}$ content in the cathode catalyst layer as well as increased conductivity of water in the anode and cathode compartments points towards $\mathrm{Ti}$ dissolution at elevated temperature. Besides the dissolution of the $\mathrm{TiO}_{2}$ support of 


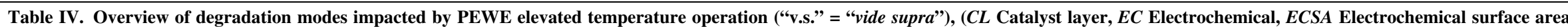
PTL Porous transport layer, FF Flowfield).

\begin{tabular}{|c|c|c|c|c|}
\hline Component & Cause & Primary Effect & Consecutive Effects & Mechanism \\
\hline Membrane & Gas crossover & Membrane decomposition & $\begin{array}{l}\text { Membrane thinning, explosive gas mixture, CL } \\
\text { short circuit }\end{array}$ & $\begin{array}{l}\text { Membrane gas permeability } f(T, p) \text {, radical } \\
\quad \text { formation } f(T)\end{array}$ \\
\hline Membrane & Deformation & Gas crossover, short circuit & Decomposition (v.s.) & Creep $f(T)$ \\
\hline CL & Ti dissolution & Membrane/CL contamination & Decomposition (v.s.), drop of $\mathrm{H}^{+}$conductivity & EC dissolution $f(T, E)$, fluoride attack $f(T, E)$ \\
\hline CL & Ir detachment & Loss of ECSA & Kinetic overpotential & $\mathrm{O}_{2}$ bubble formation $f(T, p)$ \\
\hline CL & Deformation & $\begin{array}{l}\text { Proton conductivity, electronic } \\
\text { conductivity }\end{array}$ & & Creep $f(T)$ \\
\hline PTL/FF & Ti dissolution & Membrane/CL contamination & $\begin{array}{l}\text { Membrane decomposition, drop of } \mathrm{H}^{+} \text {conduc- } \\
\text { tivity }\end{array}$ & Fluoride attack $f(T)$ \\
\hline PTL/FF & Ti passivation & Ohmic resistance & & EC oxidation $f(T, E)$ \\
\hline
\end{tabular}

PTL/FF

Ti passivation

Ohmic resistance

EC oxidation $f(T, E)$ 


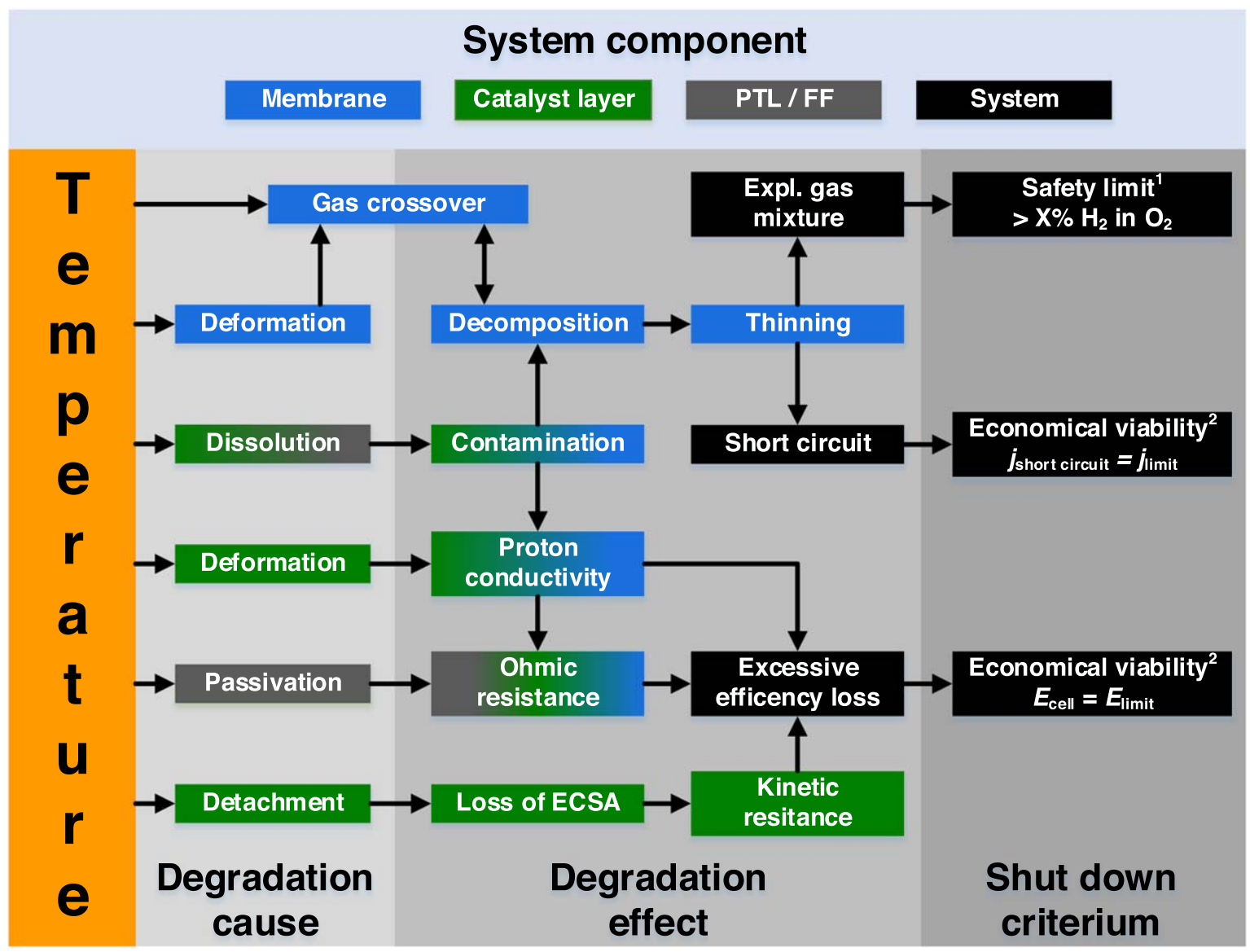

Figure 8. Diagram showing the impact of temperature (orange) as a degradation stressor in PEWE on active system components, namely membrane (blue), catalyst layer (green), porous transport layer and flowfields (PTL/FF, grey), that lead to degradation causes. The degradation causes can be detected by measurable degradation effects resulting in three shut down criteria on a system level (black). (ECSA = electrochemical surface area). ${ }^{1}$ The lower explosion limit of hydrogen in oxygen is at $4 \% \mathrm{H}_{2}$ in $\mathrm{O}_{2}$. The safety limit is set by the operator and needs to be below the explosion limit. ${ }^{2}$ The economical viability strongly depends on the local costs for energy and limiting current $j_{\text {limit }}$ as well as limiting cell voltage $E_{\text {limit }}$ defined to be set by the operator.

the anode CL, Ti ions can also be released by other Ti components in the cell. The higher amount of fluoride ions released by cell 2 $\left(100{ }^{\circ} \mathrm{C}\right)$ at the cathode were found to attack $\mathrm{TiO}_{2}$ films and release Ti ions. ${ }^{71-73}$

Summary of degradation modes.-A degradation mode describes the entirety of a degradation cause, its effects and the underlying degradation mechanism. ${ }^{80}$ Table IV summarizes the degradation modes affected by elevated temperature PEWE operation observed based on the results of this work and studies reported in literature. In most cases the degradation causes can be associated to one PEWE system component. The causes lead to primary effects and consecutive effects that are measurable on the cell-level. The causes can be explained by degradation mechanisms that are dependent on temperature and voltage.

Implications on operation time.-Figure 8 shows a diagram that connects the stressor "temperature" to active cell components and degradation modes according to Table IV. 3 PEWE shut down criteria were identified: 1 . exceeding the hydrogen in oxygen safety limit, 2. exceeding a limit of short circuit current and 3. reaching of a critical cell voltage.

Loss of the initial fluoride inventory results in membrane thinning. ${ }^{81,82}$ Localized thinning can lead to short circuits that cause a drop in the cell voltage. ${ }^{83}$ The resulting short circuit current reduces the faradaic efficiency of the PEWE cell and increases hydrogen production costs. Depending on the number of short circuits and the faradaic loss the PEWE operation might meet a critical limit.

Thinning of the membrane can lead to an increase in the rate of gas cross-over in PEWE. The hydrogen content in oxygen represents a safety issue, with $4 \%$ hydrogen in oxygen as a lower explosion limit. ${ }^{63,70}$ Operation of PEWE is therefore often restricted to a safety limit of $2 \%$ hydrogen in oxygen on the anode side. Moreover, industrial electrolyzers are operated at differential pressures of up to $30 \mathrm{bar}_{\mathrm{a}}$, which further increases hydrogen permeation. ${ }^{6}$ Although experiments in this work showed a higher gas permeation for cell 2 than for cell 1, there was no increase of the hydrogen content in oxygen observable over the $300 \mathrm{~h}$ duration. However, by taking into account the integrated FRR from Fig. 7c, over the duration of this experiment less than $0.2 \%$ and $0.5 \%$ membrane material was lost for cell 1 and cell 2, respectively (with a molar mass share of $71 \%$ of fluoride and a weight of $360 \mathrm{~g} \mathrm{~m}^{-2}$, a Nafion 117 membrane contains $255 \mathrm{~g} \mathrm{~m}^{-2}$ fluoride ${ }^{84}$ ). Considering a $10 \%$ loss of the initial fluoride inventory of the membrane in PEWE to be fatal, ${ }^{82}$ the estimated operation time of cell 1 and cell 2 would be $37,000 \mathrm{~h}$ and 3,700 h, respectively (extrapolated from the FRR at $280 \mathrm{~h}$ ). The operation time of cell 1 is about $13,000 \mathrm{~h}$ lower than what was achieved already with PEWE stacks. ${ }^{6}$ However, the FRR was reported to further decrease over time for cells operated at $60{ }^{\circ} \mathrm{C}$ for a $500 \mathrm{~h}$ duration. ${ }^{9}$

Using the mean voltage loss rates from Fig. 1a, the cell voltage of cell 2 would catch up with that of cell 1 after about $1,500 \mathrm{~h}$ (detailed calculation in Supplemental Material). Efficiency loss leads to 
increased power requirement and therefore electricity cost. Energy savings from cell $2\left(100^{\circ} \mathrm{C}\right)$ in comparison to cell $1\left(60{ }^{\circ} \mathrm{C}\right)$ would be already used up after $3,500 \mathrm{~h}$ of operation. The initial purpose of elevated temperature operation, i.e. energy savings to reduce hydrogen production cost, is therefore negated and, depending on the operation mode and location, the PEWE system becomes economically unattractive. According to a US Department of Energy report, industrial PEWE stack replacement takes place after 7 years assuming a capacity factor of $97 \%(58,000 \mathrm{~h}$ of operation) and a voltage loss rate of $1.5 \mu \mathrm{V} \mathrm{h}{ }^{-1} .{ }^{85,86}$ This gives a maximum tolerated efficiency loss of $\varepsilon_{\mathrm{LHV}}=4 \%$ to define stack end-of-life for a cell operated at $60{ }^{\circ} \mathrm{C}$. This results in a operation time of $2,000 \mathrm{~h}$ in the case of our cell $2\left(100{ }^{\circ} \mathrm{C}\right)$ considering an initial efficiency increase of $\Delta \varepsilon_{\mathrm{LHV}}=5 \%$ in comparison to $60{ }^{\circ} \mathrm{C}$ PEWE operating temperature. In consequence, excessive efficiency loss can be considered as the most limiting PEWE degradation effect regarding elevated temperature operation.

As a result, elevated temperature PEWE will only be viable if the excessive efficiency loss is mitigated to maintain energy savings. For energy savings of $0.1 \%$ over a stack operation time of seven years and an initial efficiency increase of $\Delta \varepsilon_{\text {LHV }}=5 \%$ by PEWE operation at $100{ }^{\circ} \mathrm{C}$ in comparison to $60{ }^{\circ} \mathrm{C}$ the maximal tolerated voltage loss rate is $5.8 \mu \mathrm{V} \mathrm{h}^{-1}$. This would mean a decrease of voltage loss rate by a factor of 20 in comparison to the voltage loss rate at $100{ }^{\circ} \mathrm{C}$ found in this work. Figure 2c shows that excessive efficiency loss is driven by increase in ohmic and kinetic overpotentials. From Fig. 8, we can conclude that Ti dissolution from the CL and the PTL/FFs impact both shut down criteria. In order to realize high temperature operation future research should therefore tackle these degradation causes.

\section{Conclusions}

PEWE operation at an elevated temperature of $100{ }^{\circ} \mathrm{C}$, using state-of-the art components, triggers multiple degradation modes resulting in 3 effects limiting useful life on the cell level: formation of a short circuit, an explosive gas mixture, and excessive efficiency loss. Excessive efficiency loss with a voltage loss rate of $126 \mu \mathrm{V} \mathrm{h}^{-1}$ over $300 \mathrm{~h}$ was found to be the limiting effect after a projected operation time of $2,000 \mathrm{~h}$. Elevated temperature operation with a view to energy savings due to an efficiency increase of 5\% is only viable if a voltage loss rate of less than $5.8 \mu \mathrm{V} \mathrm{h}^{-1}$ can be attained. The major voltage loss contributions at elevated temperature PEWE are ohmic (49\%) and anode kinetic losses (45\%). In future work, the degradation causes that lead to those effects need to be investigated, in particular Ti dissolution and catalyst layer particle detachment. Failure by short circuit was identified to be a limiting effect after a projected lifetime $3,700 \mathrm{~h}$. The reduction of gas crossover and presence of Fenton-active species is critical to minimize ionomer decomposition. At elevated temperature and differential pressure operation hydrogen gas crossover is limiting since a content of $4 \%$ hydrogen in oxygen displays the lower explosion limit for this gas composition.

\section{Acknowledgments}

Funding by the Swiss Federal Office of Energy (SFOE, under grant no. SI/501603) is gratefully acknowledged. SG would like to thank Dr. Ugljesa Babic for the help designing the PEWE test bench as well as Nataša Diklić and Dr Mateusz Zlobinski for the fruitful scientific discussions.

\section{ORCID}

Steffen Garbe (D) https://orcid.org/0000-0003-2920-179X Jonas Futter (D) https://orcid.org/0000-0002-8782-3952 Mohamed Tarik (D) https://orcid.org/0000-0002-1631-5520 Adrian A. Mularczyk (iD https://orcid.org/0000-0001-7919-3324 Thomas J. Schmidt (iD https://orcid.org/0000-0002-1636-367X Lorenz Gubler (iD https://orcid.org/0000-0002-8338-6994

\section{References}

1. M. J. O'Malley et al., Proc. IEEE, 108, 1437 (2020).

2. T. Smolinka, N. Wiebe, P. Sterchele, A. Palzer, F. Lehner, M. Jansen, S. Kiemel, R. Miehe, S. Wahren, and F. Zimmermann, Studie IndWEDe: Industrialisierung der Wasserelektrolyse inDeutschland: Chancen und Herausforderungenfür nachhaltigen Wasserstoff für Verkehr,Strom und Wärme, NOW GmbH (2018), http:// publica.fraunhofer.de/eprints/urn_nbn_de_0011-n-5194940.pdf.

3. G. Dispenza, F. Sergi, G. Napoli, V. Antonucci, and L. Andaloro, Journal of Energy Storage, 24, 100757 (2019).

4. S. Garbe, J. Futter, T. J. Schmidt, and L. Gubler, Electrochim. Acta, 377, 138046 (2021).

5. M. Suermann, T. J. Schmidt, and F. N. Büchi, Electrochim. Acta, 211, 989 (2016)

6. K. E. Ayers, E. B. Anderson, C. Capuano, B. Carter, L. Dalton, G. Hanlon, J. Manco, and M. Niedzwiecki, ECS Trans., 33, 3 (2010)

7. K. Ayers, High Efficiency PEM Water Electrolysis Enabled by Advanced Catalysts, Membranes and Processes, D. o. Energy Editor, Energy.gov (2018), (https://www. hydrogen.energy.gov/pdfs/review18/pd155_ayers_2018_p.pdf).

8. C. Rozain, Développement de nouveaux matériaux d'électrodes pour la production d'hydrogène par électrolyse de l'eau, Université Paris Sud - Paris XI (2013), p. 155, https://tel.archives-ouvertes.fr/tel-00923169/document.

9. S. H. Frensch, F. Fouda-Onana, G. Serre, D. Thoby, S. S. Araya, and S. K. Kær, Int J. Hydrogen Energy, 44, 29889 (2019).

10. A. Weiß, A. Siebel, M. Bernt, T.-H. Shen, V. Tileli, and H. Gasteiger, J. Electrochem. Soc., 166, F487 (2019).

11. F. Fouda-Onana, M. Chandesris, V. Médeau, S. Chelghoum, D. Thoby, and N. Guillet, Int. J. Hydrogen Energy, 41, 16627 (2016).

12. C. Rakousky, U. Reimer, K. Wippermann, S. Kuhri, M. Carmo, W. Lueke, and D. Stolten, J. Power Sources, 342, 38 (2017).

13. C. Rakousky, U. Reimer, K. Wippermann, M. Carmo, W. Lueke, and D. Stolten, J. Power Sources, 326, 120 (2016).

14. U. Babic, M. Tarik, T. J. Schmidt, and L. Gubler, J. Power Sources, 451, 227778 (2020).

15. S. Stucki, G. Scherer, S. Schlagowski, and E. Fischer, J. Appl. Electrochem., 28, 1041 (1998).

16. A. Laconti, H. Liu, C. Mittelsteadt, and R. McDonald, ECS Trans., 1, 199 (2006).

17. H. Liu, F. D. Coms, J. Zhang, H. A. Gasteiger, and A. B. LaConti, Polymer Electrolyte Fuel Cell Durability, ed. Minoru Inaba, Thomas J. Schmidt, and Felix N. Büchi (Springer, New York) 71 (2009).

18. H. Yu, N. Danilovic, Y. Wang, W. Willis, A. Poozhikunnath, L. Bonville, C. Capuano, K. Ayers, and R. Maric, Appl. Catalysis B, 239, 133 (2018).

19. S. M. Alia, K. S. Reeves, J. S. Baxter, and D. Cullen, "The Impact of Ink and Spray Variables on Catalyst Layer Properties, Electrolyzer Performance, and Electrolyzer Durability." J. Electrochem. Soc., 167, 144512 (2020).

20. S. Siracusano, V. Baglio, N. Van Dijk, L. Merlo, and A. S. Aricò, Appl. Energy, 192, 477 (2017).

21. S. Siracusano, N. Van Dijk, R. Backhouse, L. Merlo, V. Baglio, and A. Aricò, Renewable Energy, 123, 52 (2018).

22. N. Li, S. S. Araya, X. Cui, and S. K. Kær, J. Power Sources, 473, 228617 (2020)

23. C. Klose, T. Saatkamp, A. Münchinger, L. Bohn, G. Titvinidze, M. Breitwieser, K. D. Kreuer, and S. Vierrath, Adv. Energy Mater., 10, 1903995 (2020).

24. M. Suermann, B. Bensmann, and R. Hanke-Rauschenbach, J. Electrochem. Soc., 166, F645 (2019).

25. P. Marocco, K. Sundseth, T. Aarhaug, A. Lanzini, M. Santarelli, A. O. Barnett, and M. Thomassen, J. Power Sources, 483, 229179 (2021).

26. L. Gubler, S. M. Dockheer, and W. H. Koppenol, J. Electrochem. Soc., 158, B755 (2011).

27. U. Babic, E. Nilsson, A. Pătru, T. J. Schmidt, and L. Gubler, J. Electrochem. Soc., 166, F214 (2019)

28. M. Bernt and H. A. Gasteiger, J. Electrochem. Soc., 163, F3179 (2016).

29. A. Albert, T. Lochner, T. J. Schmidt, and L. Gubler, ACS Appl. Mater. Interfaces, 8 , 15297 (2016)

30. S. Grigoriev, D. Bessarabov, and V. Fateev, Russ. J. Electrochem., 53, 318 (2017)

31. C. Rozain, E. Mayousse, N. Guillet, and P. Millet, Appl. Catalysis B, 182, 153 (2016).

32. C. Rozain, E. Mayousse, N. Guillet, and P. Millet, Appl. Catalysis B, 182, 123 (2016).

33. K. A. Lewinski, D. van der Vliet, and S. M. Luopa, ECS Trans., 69, 893 (2015).

34. T. Schuler, T. J. Schmidt, and F. N. Büchi, J. Electrochem. Soc., 166, F555 (2019)

35. A. B. LaConti, M. Hamdan, and R. C. McDonald, "Mechanisms of Membrane Degradation." Handbook of Fuel Cells, ed. W Vielstich, H. A. Gasteiger, and A. Lamm (Wiley, Chichester, United Kingdom) 3, 647 (2003).

36. U. Babic, M. Suermann, F. N. Büchi, L. Gubler, and T. J. Schmidt, J. Electrochem. Soc., 164, F387 (2017).

37. Q. Feng, G. Liu, B. Wei, Z. Zhang, H. Li, and H. Wang, J. Power Sources, 366, 33 (2017).

38. T. Schuler, T. Kimura, T. J. Schmidt, and F. N. Büchi, Energy Environ. Sci., 13 2153 (2020).

39. M. Bernt, A. Siebel, and H. A. Gasteiger, J. Electrochem. Soc., 165, F305 (2018)

40. K. Ayers, N. Danilovic, R. Ouimet, M. Carmo, B. Pivovar, and M. Bornstein, Annual Review of Chemical and Biomolecular Engineering, 10, 219 (2019).

41. M. Suermann, K. Takanohashi, A. Lamibrac, T. J. Schmidt, and F. N. Büchi, J. Electrochem. Soc., 164, F973 (2017).

42. S. J. Osborn, M. K. Hassan, G. M. Divoux, D. W. Rhoades, K. A. Mauritz, and R. B. Moore, Macromolecules, 40, 3886 (2007) 
43. J. T. Hinatsu, M. Mizuhata, and H. Takenaka, J. Electrochem. Soc., 141, 1493 (1994).

44. U. Babic, M. Zlobinski, T. J. Schmidt, P. Boillat, and L. Gubler, J. Electrochem Soc., 166, F610 (2019).

45. L. S. Karaffa, The Merck Index: An Encyclopedia of Chemicals, Drugs, and Biologicals (Royal Society of Chemistry, United Kingdom) (2013).

46. C. Van Pham, M. Bühler, J. Knöppel, M. Bierling, D. Seeberger, D. Escalera-López, K. J. Mayrhofer, S. Cherevko, and S. Thiele, Appl. Catalysis B, 269, 118762 (2020).

47. S. Cherevko, T. Reier, A. R. Zeradjanin, Z. Pawolek, P. Strasser, and K. J. Mayrhofer, Electrochem. Commun., 48, 81 (2014).

48. S. M. Alia, B. Rasimick, C. Ngo, K. Neyerlin, S. S. Kocha, S. Pylypenko, H. Xu, and B. S. Pivovar, J. Electrochem. Soc., 163, F3105 (2016).

49. M. Pourbaix, Atlas of Electrochemical Equilibria in Aqueous Solutions (National Association of Corrosion Engineers (NACE), Houston TX) 213 (1974)

50. F. Alcaide, R. V. Genova, G. Álvarez, H.-J. Grande, Ó. Miguel, and P. L. Cabot, Int. J. Hydrogen Energy, 45, 20605 (2020)

51. Y. Xiao, N. Cheng, K. K. Kondamareddy, C. Wang, P. Liu, S. Guo, and X.-Z. Zhao, I. Power Sources, 342, 489 (2017).

52. H. Y. Lee, C. Barber, and A. R. Minerick, Electrophoresis, 35, 1782 (2014).

53. C. Spoeri, J. T. H. Kwan, A. Bonakdarpour, D. P. Wilkinson, and P. Strasser, Angew. Chem. Int. Ed., 56, 5994 (2017).

54. A. R. Zeradjanin, A. A. Topalov, Q. Van Overmeere, S. Cherevko, X. Chen, E. Ventosa, W. Schuhmann, and K. J. Mayrhofer, RSC Adv., 4, 9579 (2014).

55. O. Panchenko, M. Carmo, M. Rasinski, T. Arlt, I. Manke, M. Müller, and W. Lehnert, Materials Today Energy, 16, 100394 (2020).

56. M. Zlobinski, T. Schuler, F. N. Büchi, T. J. Schmidt, and P. Boillat, J. Electrochem. Soc., 167, 084509 (2020).

57. W. Hu, S. Chen, and Q. Xia, Int. J. Hydrogen Energy, 39, 6967 (2014).

58. A. Pavlišič, P. Jovanovič, V. S. Šelih, M. Šala, N. Hodnik, and M. Gaberšček, J. Electrochem. Soc., 165, F3161 (2018).

59. S. Mitsushima, Y. Koizumi, S. Uzuka, and K.-I. Ota, Electrochim. Acta, 54, 455 (2008).

60. M. Zlobinski, U. Babic, M. Fikry, L. Gubler, T. J. Schmidt, and P. Boillat, J. Electrochem. Soc., 167, 144509 (2020).

61. P. Trinke, B. Bensmann, and R. Hanke-Rauschenbach, Int. J. Hydrogen Energy, 42 14355 (2017).

62. M. Schalenbach, T. Hoefner, P. Paciok, M. Carmo, W. Lueke, and D. Stolten, The Journal of Physical Chemistry C, 119, 25145 (2015).

63. S. Garbe, U. Babic, E. Nilsson, T. J. Schmidt, and L. Gubler, J. Electrochem. Soc., 166, F873 (2019)

64. A. Albert, A. O. Barnett, M. S. Thomassen, T. J. Schmidt, and L. Gubler, ACS Appl. Mater. Interfaces, 7, 22203 (2015).
65. H. Ben youcef, L. Gubler, S. A. Gürsel, D. Henkensmeier, A. Wokaun, and G. G. Scherer, Electrochem. Commun., 11, 941 (2009).

66. M. Takasaki, Y. Nakagawa, Y. Sakiyama, K. Tanabe, K. Ookubo, N. Sato, T. Minamide, H. Nakayama, and M. Hori, ECS Trans., 17, 439 (2009).

67. M. Inaba, T. Kinumoto, M. Kiriake, R. Umebayashi, A. Tasaka, and Z. Ogumi, Electrochim. Acta, 51, 5746 (2006).

68. M. Danilczuk, S. Schlick, and F. D. Coms, The Chemistry of Membranes Used in Fuel Cells: Degradation and Stabilization, ed. S. Schlick (Wiley, Hoboken NJ) 75 (2018).

69. M. Schalenbach, M. Carmo, D. L. Fritz, J. Mergel, and D. Stolten, Int. J. Hydrogen Energy, 38, 14921 (2013).

70. M. Bernt, J. Schröter, M. Möckl, and H. Gasteiger, J. Electrochem. Soc., 167, $124502(2020)$

71. Z. Wang, H. Hu, C. Liu, and Y. Zheng, Electrochim. Acta, 135, 526 (2014).

72. D.-S. Kong and Y.-Y. Feng, J. Electrochem. Soc., 156, C283 (2009).

73. M. Nakagawa, S. Matsuya, T. Shiraishi, and M. Ohta, J. Dent. Res., 78, 1568 (1999).

74. P. Tengvall, H. Elwing, and I. Lundström, J. Colloid Interface Sci., 130, 405 (1989).

75. P. Lettenmeier et al., Electrochim. Acta, 210, 502 (2016).

76. T. Xie, K. A. Page, and S. A. Eastman, Adv. Funct. Mater., 21, 2057 (2011)

77. J.-T. Wang, W.-W. Wang, C. Wang, and Z.-Q. Mao, Int. J. Hydrogen Energy, 37, 12069 (2012)

78. G. Lu, S. L. Bernasek, and J. Schwartz, Surf. Sci., 458, 80 (2000)

79. C. Liu, M. Carmo, G. Bender, A. Everwand, T. Lickert, J. L. Young, T. Smolinka D. Stolten, and W. Lehnert, Electrochem. Commun., 97, 96 (2018).

80. T. J. Schmidt, Polymer Electrolyte Fuel Cell Durability, ed. M. Inaba, T. J. Schmidt, and F. N. Büchi (Springer, Berlin) 199 (2009).

81. C. S. Gittleman, F. D. Coms, and Y.-H. Lai, Polymer Electrolyte Fuel Cell Degradation, ed. M. M. Mench, E. C. Kumbur, and T. N. Veziroglu (Academic Press, Boston MA) 15 (2012)

82. C. Mittelsteadt, T. Norman, M. Rich, and J. Willey, Electrochemical Energy Storage for Renewable Sources and Grid Balancing, ed. P. T. Moseley and J. Garche (Elsevier, Amsterdam) 159 (2015).

83. S. P. S. Badwal, S. Giddey, and F. T. Ciacchi, Ionics, 12, 7 (2006).

84. K. A. Mauritz and R. B. Moore, Chem. Rev., 104, 4535 (2004).

85. B. D. James, D. A. DeSantis, and G. Saur, Hydrogen Production Pathways Cost Analysis (2013-2016) (Strategic Analysis Inc., Arlington, VA (United States of America)) (2016).

86. W. G. Colella, B. D. James, J. M. Moton, G. Saur, and T. Ramsden, Electrolytic Hydrogen Production Workshop (NREL, Golden, Colorado) (2014). 